\title{
SPEECH TEST STUDIED BY MEANS OF CONFUSION MATRIX
}

\author{
By \\ T. EBIHARA \\ From the Oto-Rhino-Laryngo'ogy, Tokyo Medica! and lienta! \\ University (Director: Prof. S. Horiguchi
}

In order to obtain more exact results in speech test, the list of the words has to be reasonable from the stand point of confusion test among the speech words. However, confusion patterns among the speech words have not been derived upto date.

Moreover, articulation scores for respective speech words could be obtained from the confusion matrix. Thus, the author could find a reasonable word lists for speech test.

If the speech words are classified in the two groops, i.e. the direct sound and the contracted sound groop, the same confusion pattern can be found in the two groops. Therefore, the words list for speech test can be reasonably arrenged with only monosyllable sounds belonging to the direct sounds groop.

The six words that is $n i, d e, b e, p e, d a$ and $d o$ must be omitted from the werds list because these words are very frequently confused with other words even in normal persons. The list contains 60 words.

The total articulation score of this list for normal persons is calculated as $98 \%$ from canfusion matrix previonsaly obtained for direct sound groop.

The list has been proved as more suitable in differentiation of nerve deafunss than any other lists in clinical use.

\section{Confusion Matrix による日本語音聴力㭘查法の研究}

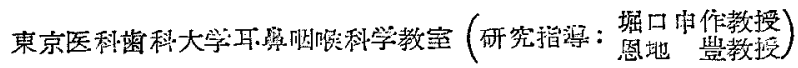

$$
\begin{aligned}
& \text { 海老原悡实 }
\end{aligned}
$$

\section{第1 章、緭 置 \\ 第2 章 砳笢方法友び測定法 \\ 第3 碚究激照 \\ 第 4 章 研笲成縝}

1）日本語の綜合明你度

i）語畄の强さ $70 \mathrm{j} \mathrm{db}$ に対与る正常耳:分綜合明 睽度

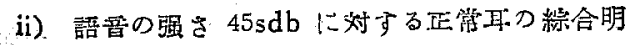
嘹度

iii）語吾の强さ 30 s db に対する正常耳の綜合朋 睹院

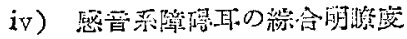

2) 各哣要別明膫度

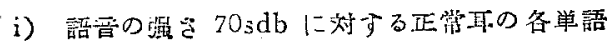

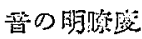

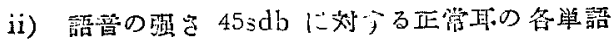

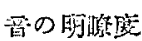

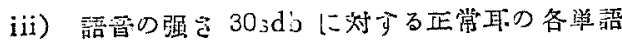

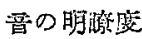

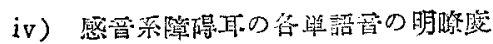

3）行別誤聴榄溙

i) 正常耳: $70 \mathrm{sdb}$ の行㓢誤聴模棁

ii) 正常耳 $45 \mathrm{sdb}$ の行別譟㯖模様 
iii) 正常开: $30 \mathrm{sdb}$ の行別誤徳模㥞

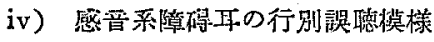

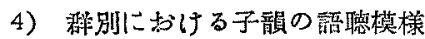

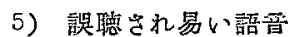

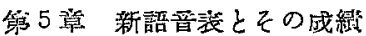

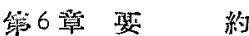

\section{第 1 章 緒 言}

オージオメーダーの発明以来揨断用として純音聴才検 查法の，色ヶのものが考案され発達して来たが，聴力の 社会能力を判定するに必要な語音聴才検查は未だ不充分 である・聴力の最も大切な目的は語音の聴取でありそ の語音聴力を直接測定するのは語音㭘查による以外にな い.この晏響医学的研究上外に通信上の誤聴の原因とか

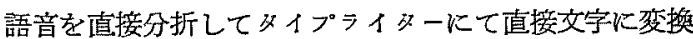
する方法の基礎的䃌究として語音のConfusion Matrix の研究は大切である・故に，語音聴力検查の基礎的デー ターを得る必要がある.

語音聴力検查法け主として，聴取された語音の誤聴の 程度を判定する方法に主目的を置いているが，日本語に ついて誴聴の状態がいかなるものであるかる正常耳更び

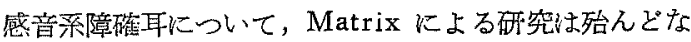
w.

著者は日本語の誤㙏状態を 测定するのに有効な Confusion Matrix (混同行列) 方式を用い，䶂聴の状態に ついてのデーターを得，これにもとずいて語音聴力検査

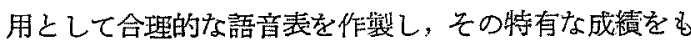
得たので発素する。

\section{第 2 章 研究方法及び測定法}

使用語音は邦語 50 音図中惯用上共通なるのは1つに まとるて，これらから棈成される直音 67 音，拗音群 33 音, 合計 100 音の単音節を訓令式口ーマ字で表わし た・

日本語音は子禎，母韻は融合して使用されているた

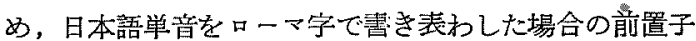
音を子韻とし，後続母音を母韻とした。即ら日本語は a i u e o の 5 ヶの母韻と 25 ケの子韻とから褋成されて いるので, 直音群では wa は1語しかなく, da 行は, da de do-しかないのでこれら以外では前置子韻と a i u e o D順で組合せると 5 の組合せで周期となる・

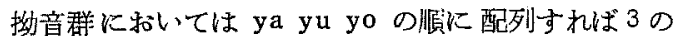
緅合せで周期となるので，この㧺にして Matrix に整 理した。
1) 測定装置: 一

身通工 G.T4 型テープレコーダー，永岛 NA1 型ス ピーチアンプ, 及仗 Scotch sound recording Tape を組合せて使用した・受話器は動電型 Fujiki MR-50 を用い，同受話器を Tapecorder Speech Amp. に接 続して 6cc のカプラーにて测定した綜合出力周波数 特性は第1図であり 1000 を Odb とすると 250ه〜 8,000の の間にあつては 士2db 以内の特性である.

第 1 図

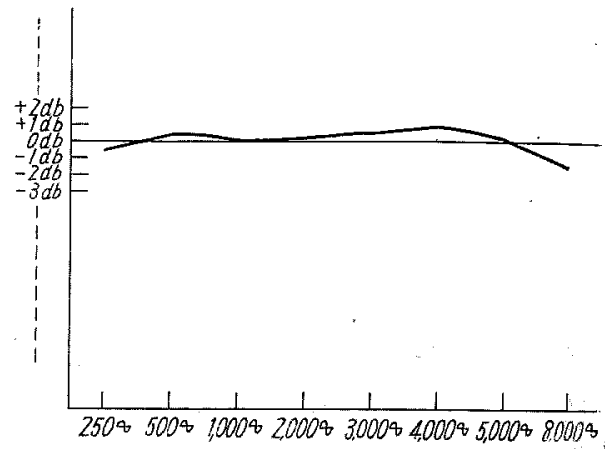

2）録音及び再生方法 :-

NHK 女子アナンサーを使用し，前記の日本語を3 秒毎に発音させ，との音圧は日本䉓測器 SL-5S noise

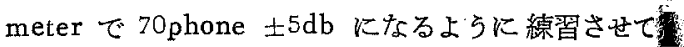
これを scotch sound recording Tape に録音し， そ れを受話器に堌幅再生した。

3）語音検查法 :-

東京医科蒾科大学難㯖研究所属防音空内で，被険者占 聴えた通りを各語音毎に復唱させ，これを語音表と参崛 して正誤を Check して䛊聴成續を求めさ。

著者の経験では，被検者の語音聴取を被検者自身湆 き取らせて, その店答から誤聴を求める彷来の方法は,

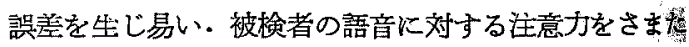
げたり，誤記する機会るあるため，同一被喻者に繰戗返 して行つた語音聴力検查成績では，変動がかなり見られ る被検者があるが前記の複唱法では更に安定した成續解 得られるのを認めたので被検者の応答は復唱法をのみ用 いた。

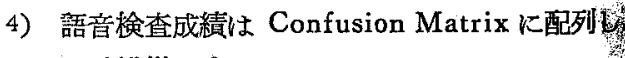
誤聴模赤を求めた。

Confusion Matrix とは第l表の如く，表の左従輁 k a i u e o, ka ki ku ke ko,...........bya byu by の順に 100 語音を配列させ，それと同じ順列に最上段の 横行に 100 語を並べ，これらの配列は単独母音, 直音, 
第 1 表 正 常 耳 70sdb の Confusion Matrix

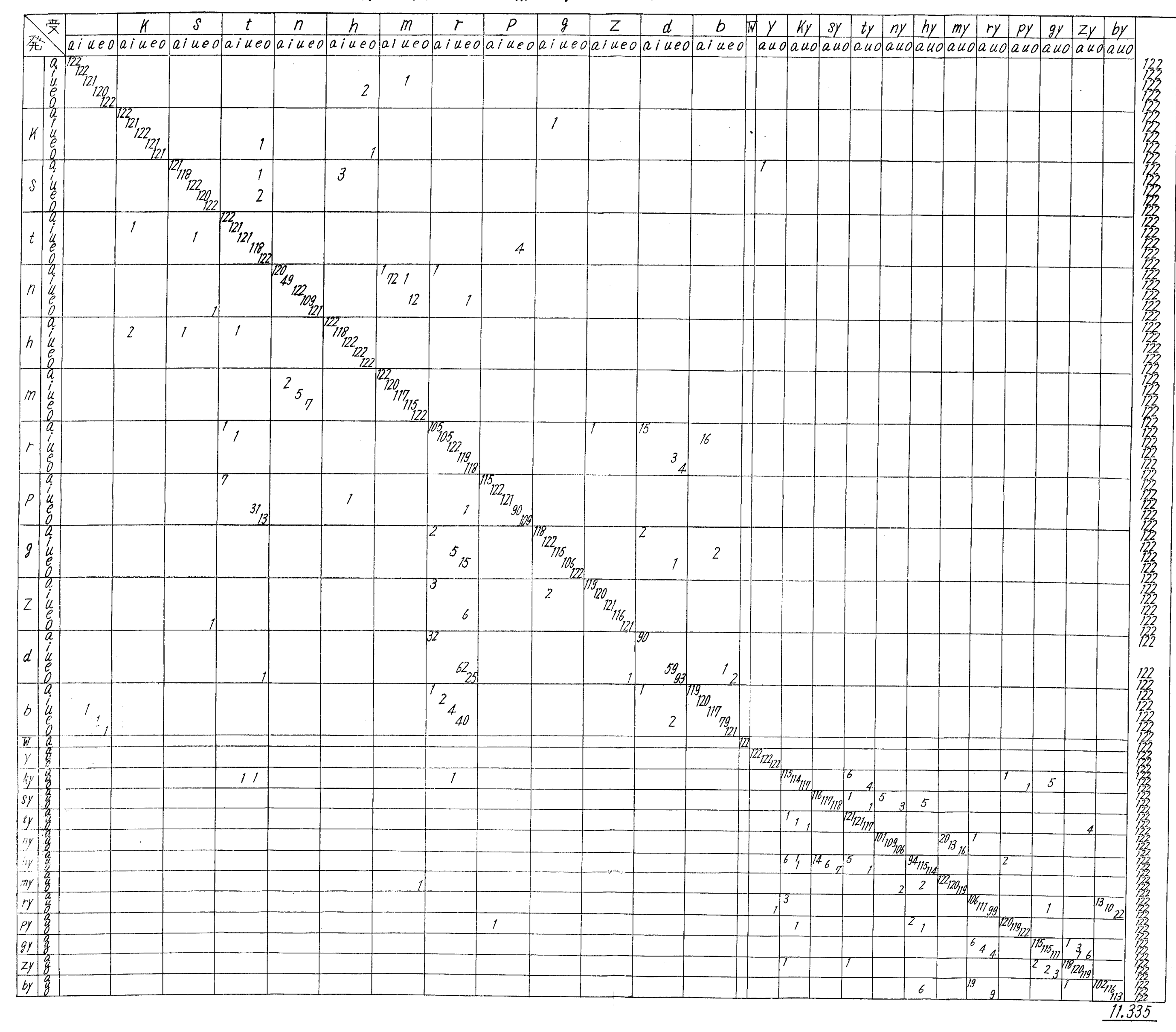

第 2 表 正 常 耳 455db の Confusion Matrix

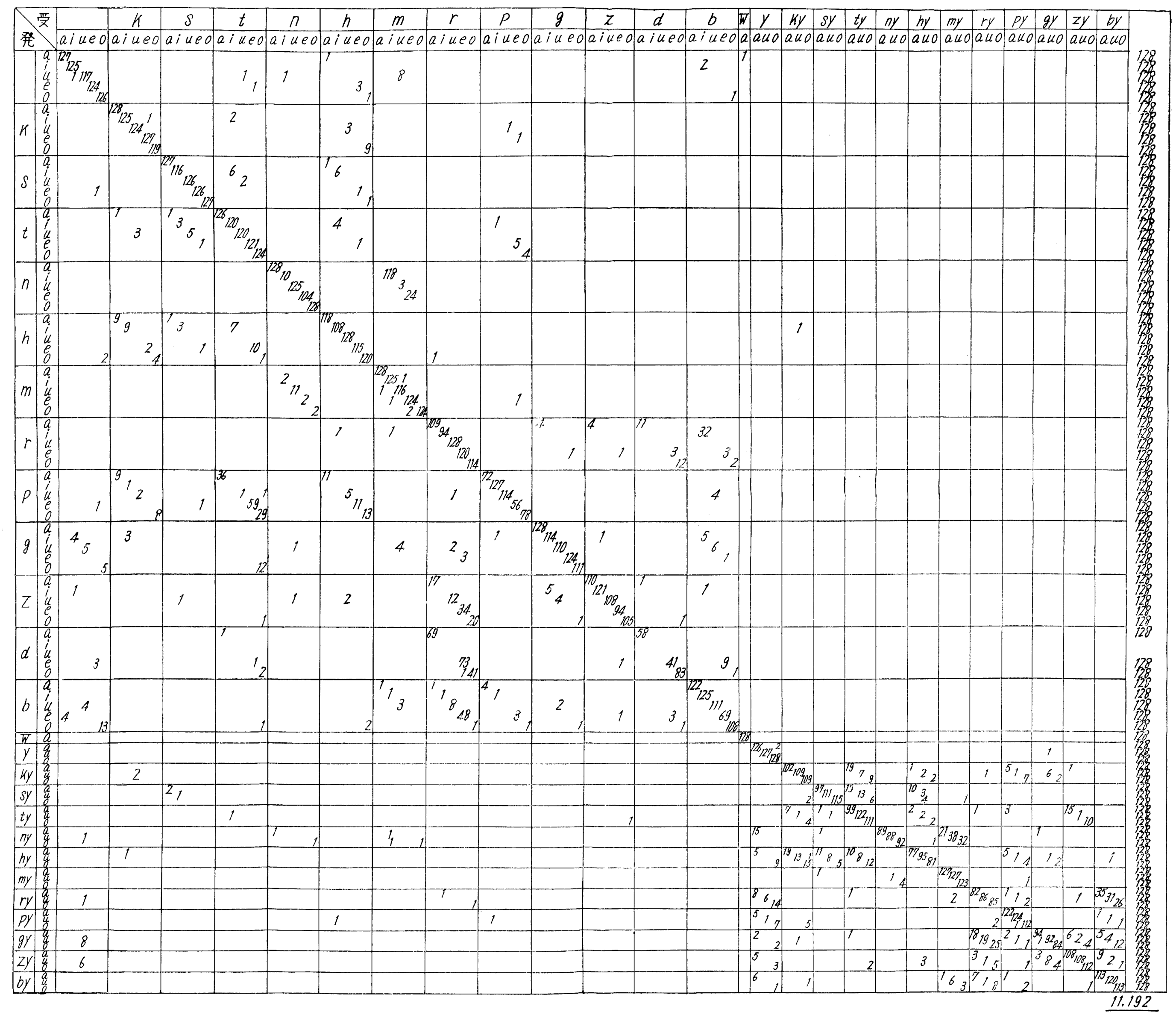


第 3 表 正 常 耳 30sdb の Confusion Martiix

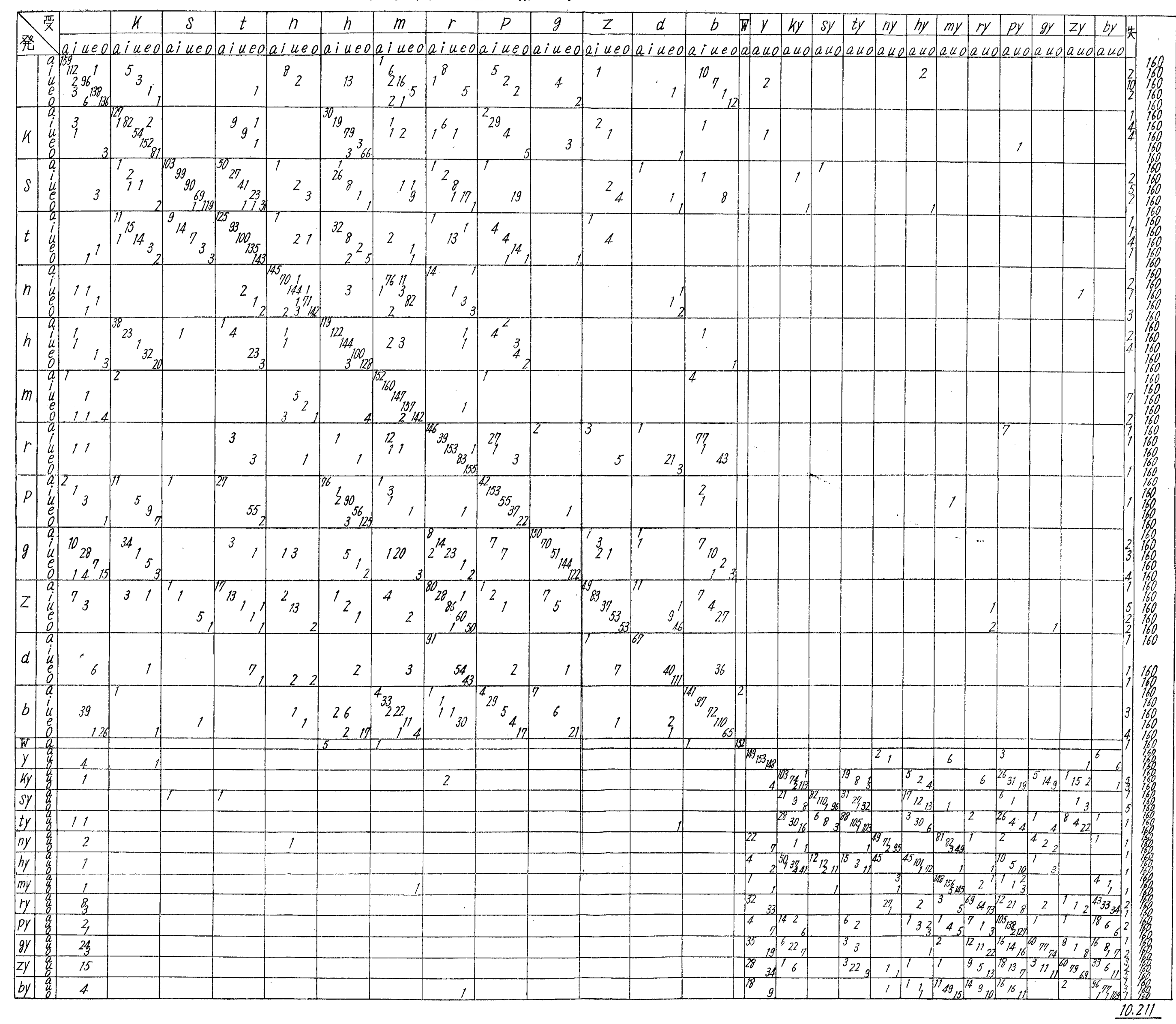

第 4 表感音系障碍耳の Confusion Matrix

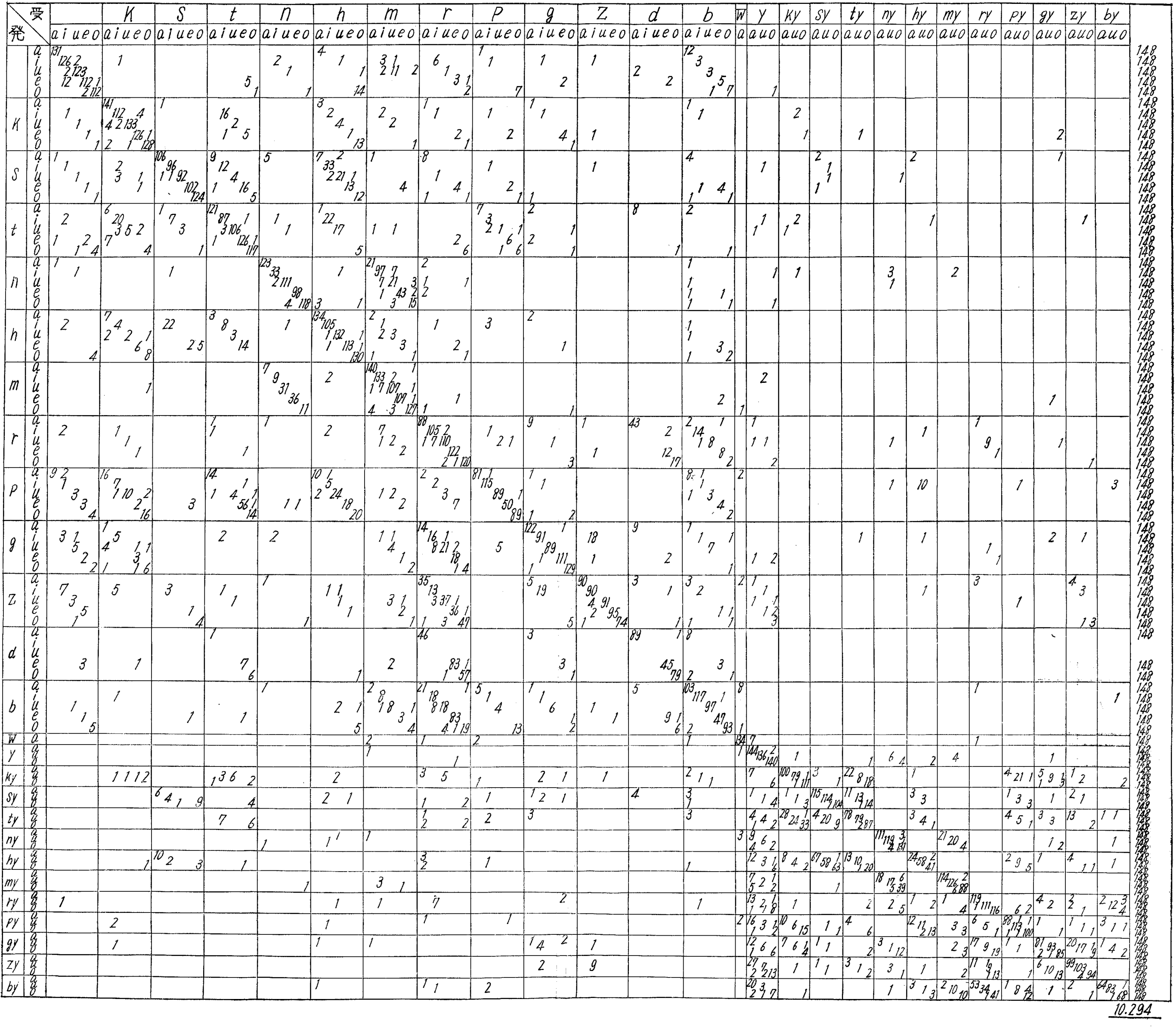


㹢母音及び拗音とした・ある語音が何回か発信されそれ 飞対する聴取され灾答の回数を発信された語音の行と， 受信された語音の列との交叉区割を記入することによ り，行列配置即ち Matrix が作られる.このようにす れば正しく受信された回数は対角線上に示されることに なる. 対角線上の区割に記入された応答回数は誤聴の 回数を示すこととなる。これが語音倸鳃の Confusion Matrix である。

第1表に示す如く，ni と云う語音が122回発せられ， mi K72 回䛊聴された埸合，ni の行と mi の列との交 叉区割に 72 と記入する・そして ni と正しく聴取され た回数は ni の行と列との交叉区割に記入することによ つて, 正の応答の回数が対庙線上区劃内に表示されるよ らになる・対角線上外の区劃にある数字は唄聴した応答 の回数になるから，このような Matrix 表示によつて 明瞭度とか，誤聴の模樣が各語音毎に容易に明瞭に区別 できる。

\section{1) 正 常 耳:-}

日本語 100 語音を前記 1）の装置及び 2）の方法によ り，正常耳 45 耳について再生語音を恥取させ，この場 合の再生浯音の強さは，閏值上 $30 \mathrm{sdb} 45 \mathrm{sdb} 70 \mathrm{sdb} の$ レベルで夫々の検查回数は $30 \mathrm{sdb}$ では各耳について約 3 回で合計 160 回 $45 \mathrm{sdb}$ では 128 回 $705 \mathrm{db}$ では 122 回 触取させた・

2) 聴力障碍耳:-

聴力障碍耳に対しては, 気導, 悬導, 耳栓骨導等か, 感音䒺難聴のものを撰択し，更にその聴力損失が Speech range で比較的平坦なるのそ50耳撰択した。それ 5の平均㯖力損失は. $30 \mathrm{sdb} \sim 80 \mathrm{~s} \mathrm{db}$ レベルの筫囲内に ある・

その語音明瞭度は与皇再生語音の強さによつて变化 するので，被検者の成績には夫々の最大明辟度を対象と して比較した.

各語音に対する検查回数は殆んどの各耳について3回 づ合計 148 回である.

\section{第 4. 章 研 究 成 績}

1) 正常耳の綜合明瞭度

i）語音の強さ $70 \mathrm{sdb}$ に対する綜合明瞭度

第 1 表は 70sdb の語音に対する正常耳の Confusion Matrix である.この测定では 100 語が夫た 120 回発信 されている・表の対角線上の区劃に見られる．即ち正の 応答数は 11.335 で発信数 12.200 に対して百分率で表わ
すと i）の条件に対する正常耳の綜合明瞭度となる。

$70 \mathrm{sdb}$ の語音の強さ法最大明䐲度が得られるレベルに 達しているので,ここで得られた 100 語音の明膫度93\% は，100語音に対する最大綜合明膫度とみなされる。

往来の語音表で得られる最大明瞭度は 100 語全部含え でいないから，日本語の語晊に対する綜合明膫度でな い.日本語去の綜合明瞭度は100 語の Matrix から得 られる・ しかもこの Matrix の值は多数の正常耳の平 均でもあるから正䂠な值が得られることになる・かくの 如くして Matrix によつて得られた日本語の綜合明嘹 度は93\%であつた。後藤及び梅垣は Matrix で整理し たものでないが前記 100 語音を $503 \mathrm{db}$ のレでルのみで 発信回数 5,000 でその綜合明睹度は92\%であり，著者 の綜合明嘹度 93\%とよく一致しているが，この董かな 相違は語音の強さによつていると思われる。

綜合明瞭度を直音群と拗音群とに分けて更に調查する には直音群と拐音群との夫ふの small Matrix を作れ ばよい。これは第1表より直らに得られる。これが Matrix 洼の便利な点である。

直音群の s.mat.より得られる綜合明瞭度は９3\%であ り，同様に拗音群の s. mat.より得られる綜合明膫度 あ93\%であつた。

ii）語音の強さ $45 \mathrm{sdb}$ に対する正常耳の綜 合明瞕度

第2表快 45sdb の Confusion Matrix である.100 語音が夫心 128 回發信され，表の対角線上の区剽の正の 応答回数の合計は11.192である。これを百分率に現わ した 100 語の綜合娟䟢度は80\%である。

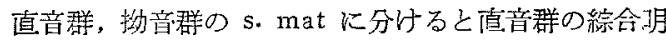

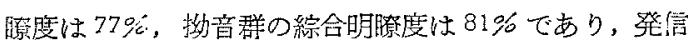
語音 $45 \mathrm{sdb}$ レべルおいては直音群は桝音群よりも綜 合明暸度が $4 \%$ 劣つている。

iii）證音の強さ30sdb 対す万正常耳の綜 合明瞭度

第3表は 30sdb レべルの Confusion Matrix であ る. 100 語音が夫々 160 回発信され，正の応答の区剽の 合計は 10.211 であり，その綜合明瞭度は63\%である。

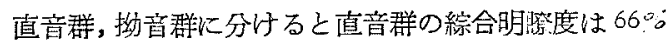

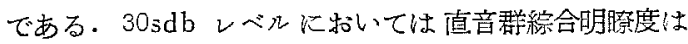
拗音群の綜合明睹度より $8 \%$ 良くなつている。

iv）感音采障馣耳の綜合明瞭度

病耳に拟いて正常耳に和いても語音明瞭度は語音の 強さによつて変化するから，これらの明瞙度を比較する 
には夫々の最大明膫度に蛙いてのみ正常耳と病耳と比較 される・病耳は伝音系障碍耳之感音采障碍耳があるが， 伝音系障碍耳の最大明膫度は，正常耳之同じものが得ら れるから，本研究では純感音系障確耳を耳柽骨導差が 250の 800ゅで $10 \mathrm{db}$ 以上のものを撰び検查の対象とし た.

検㚗刘象は絈感音采障碍耳（被検者の 各耳平均聴力損失 $30 \mathrm{db} \sim 8 \mathrm{cdb}$ のる を含む)で,これらの病耳に対して検查 語音を増幅して与え, この場合に得られ る最大明膫度より Confusion Matrix を作製した。

第 4 表の如く本検查では 100 語音が夫 \& 147 回発信され，それらの正の応答数 即方 Matrix の対争線上の区劃内数の 合計は 10.294 であり，それよりの綜合明 瞭度は $69 \%$ 之計算された。

直音群と拗音群の s. mat. に分ける と直音群の”綜合明瞭度は77\%であり， 拗音群の乞れは $63 \%$ である。

正常耳の最大明瞭度が得られる闎值上 $70 \mathrm{sdb}$ の語音の綜合明瞭度は93\%であ るに対して，病耳各耳の闖值上 $30 \mathrm{~s} \mathrm{db}$

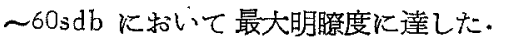
この綜合明膫度は69\%である.

病耳では直音群は $77 \%$ ，拗音群は 64 \%と両群の間に美があるが正常耳では両 群共に 93\%であつた. 然し正常耳にあ つてる检㚗語音が弱くなると，例えば閵 值上 $30 \mathrm{sdb}$ では拗音群は直音より明膫 度が落ら病耳と同橦になつている。

以上を表示すると下の如くになる。

\begin{tabular}{|c|c|c|c|}
\hline & $\begin{array}{l}\text { 語育の } \\
\text { 强さ }\end{array}$ & 群 明瞭度％ & $\begin{array}{l}\text { 䌨 弇 } \\
\text { 膫度 }\end{array}$ \\
\hline 正 & $70 \mathrm{sdb}$ & $\left\{\begin{array}{l}\text { 直音群—93\% } \\
\text { 拗音群—93\% }\end{array}\right\}$ & $93 \%$ \\
\hline 常 & $45 \mathrm{sdb}$ & 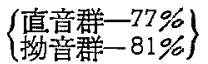 & $79 \%$ \\
\hline 耳 & $30 \mathrm{sdb}$ & 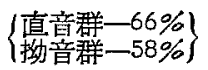 & $62 \%$ \\
\hline $\begin{array}{l}\text { 盛障 } \\
\text { 意碍 }\end{array}$ & 姑最 & 直意臂一-77\% & $69 \%$ \\
\hline
\end{tabular}

2) 各語音別明瞙度 :

i）語音の強さ $70 \mathrm{sdb}$ に対する 正常耳の各単語の明瞭度
語音発信回数で対角線上の 1 つ区劃内の正の応答回 数を調べることによつて，1つの語音の明稪度が求めら れる. 例完ば ra と 122 回発信され，ra と正の応答数 が105であつた場合これを百分率で表わすととの語音 ra の明瞭度 $86 \%$ が得られる訳である.

第 5 表は再生語音の強さ $70 \mathrm{sdb}$ 即方最大明瞭度に達

第 5 表 正常耳. $70 \mathrm{sdb}$
$/ n_{\mathrm{i}} 4 / 2 \%$ 6 do $9312.76 \%$

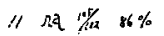
16 ne $10 \%$ sis $89 \%$ 2t b\% "ly $92 \%$ 26 PA $110 \%$. $94 \%$ 31 ze "yra $95 \%$ 36 190 $11 \% 9 \%$ 4i tis 紧 $77 \%$ 4o ne 57 2\% "1in $98 \%$ 58 pra $1 \%$

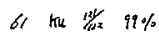
of to $5 \%$ m $99 \%$ 26 ki w/2 $99 \%$ $36 \quad 0 \quad 30 \% 100 \%$ 81 ta If he the $00 \% 100 \%$ 9f nut $100 \%$ 96 YX $10 \% 2$
2 de $5 \% / 2$ 48\% $?$ hin $7 \%$ 12 ni $15 / 1286 \%$ 17 po $10 \% 28 \%$ 22 hilu $27 \mathrm{kd} 1 / 12 \mathrm{~s}$ 94\% 32 sर将 $95 \%$ 37 siu 4 \% $96 \%$ \% no "ws $97 \%$ 47 22 $14 \%$ 98\% s2 se $10 \% 28 \%$ 57 mis

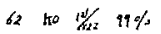
6) pu $194299 \%$ 22 the $99 \%$ 27 k4 $10200 \%$ i2 to $1272100 \%$ 87 the $1021 / 1, \ldots \%$ q2 Pi $1072100 \%$ 97 化紫 $100 \%$

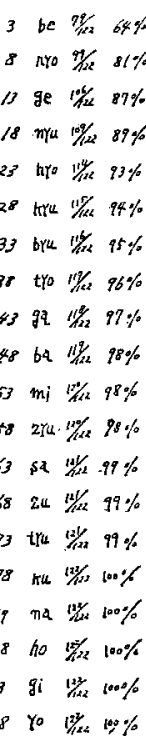

$\begin{array}{llll}3 & b c & 7 \% & 6 \% \% \\ 8 & n \% 0 & 9 / 2 & 81 \%\end{array}$

13 ge $10 \% 287 \%$

18 mu $10 \%$ se $89 \%$ 23 hyo $11 \mathrm{y}^{2} \quad 93 \%$ 28 trou $11 / 4 / 46 \%$ 33 bru 1126. 3r tho $11 \%$ \% $96 \%$ 43 程 $1129 \%$ 48 62. $11 \% 29 \%$ $53 \mathrm{mi} 19 \% 1 \mathrm{~kg} 98 \%$

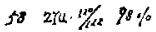
63 se $14 / 21.99 \%$ $68 \quad 24 \quad 14 / 299 \%$ 93 tru

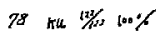
79 na $112100 \%$

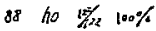
$93 \quad g_{i} \quad 1201000 \%$ $98 \quad$ Yo $1020 \%$
4 pe $9 \% / 280$ $9 \operatorname{mrd} 1228 \%$ 14 aro $10 \%$. $89 \%$ 17 AYL $11 / 22, \%$ 2* me 27 grd $4 / 232 \%$

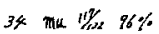
39. $31.42 \%$ 44 5Y० $111 \%$. $77 \%$

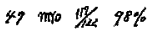
$542 i \quad 12 / 429 \%$ 59 e $121 / 49 \%$ 64 ti $\quad 7 / 229 \%$ 69 30 $11 \% 1 \%$ 97\% 74 a 管 $100 \%$ 72 sk $121 \%$ 100\% $8 \%$ Tार $1020200 \%$ 89 形炇 $100 \%$ 98 go $\operatorname{liv}_{22} 100 \%$ 99 mid $10 \%$
5 da $70 \%$

10 bit is $27 \mathrm{ra} 10 \% 87 \%$ $2091011 / 228 \%$ so giu una $98 \%$ 35 bu $120 \%$ ps te $11 \%$ 97\% sor 27t 1's $97 \%$ so pru uy $98 \%$ 55 b $48 \%$ $60 \mathrm{kn} 121 / 2.97 \%$ 65 tw 2428 70 bo $14029 \%$

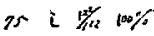
80 so $10 \% 100 \%$ $85-$ the 90 गु० $18 \%$ 95 - $121210 \%$ 100 Plo $122 \mathrm{~m} 100 \%$ 25 gie $111249 \%$
第 6 表 正常开 $45 \mathrm{sdb}$

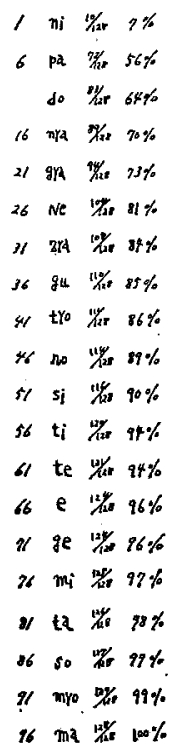

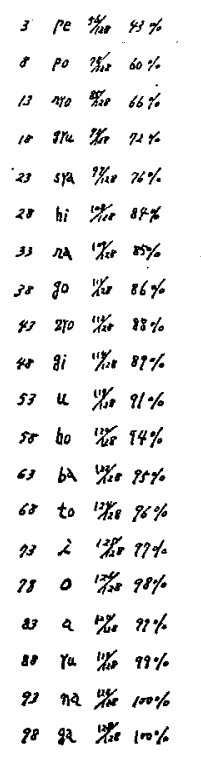

$x$ da $50.5 \%$ , fir $6 \%$ 18 a) "y $67 \%$ $\Rightarrow$ ni $7 \%$

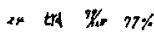
$27 \quad 24 \quad 1 \% 24 \%$ $34 \quad \mathrm{krk} \quad \mathrm{ag}+85 \%$ 39 be $11 / 4$, $86 \%$ of by 140

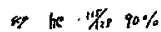

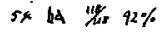
st re $20 \%$ at the 19\% $95 \%$ 67 me $120 \%$

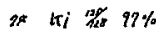
77 su 1469 so be $89 \pi / 4$ l\% $97 \%$ ge no $12 \%$ 77 wa $10.0 \%$
5 be $8 \% 5 \%$ 10 17 " $40 \%$ 15 nys 4606 20 2e the $33 \%$

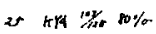
3o bo $1 \%$ gs 40 stu $86 \%$

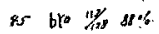
so s7o "10\% $70 \%$ so the "yit $22 \%$ so bia $120 \%$ 65 PYA 唯 $95 \%$ 20 mo 2006 95 ne 40 so se $196 \%$ s5 sh u $\pi \%$ 90 mike res $97 \%$

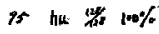
10 yo $100 \%$ 
第7表 正 常 耳. $30 \mathrm{sdb}$

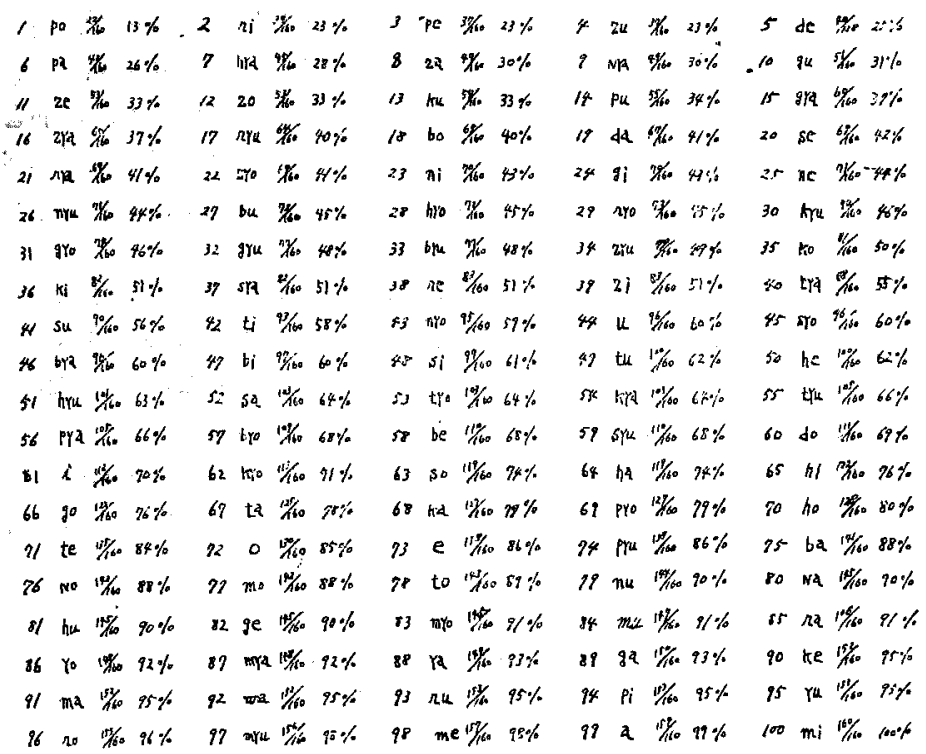

第 8 表 感番系愃碍耳

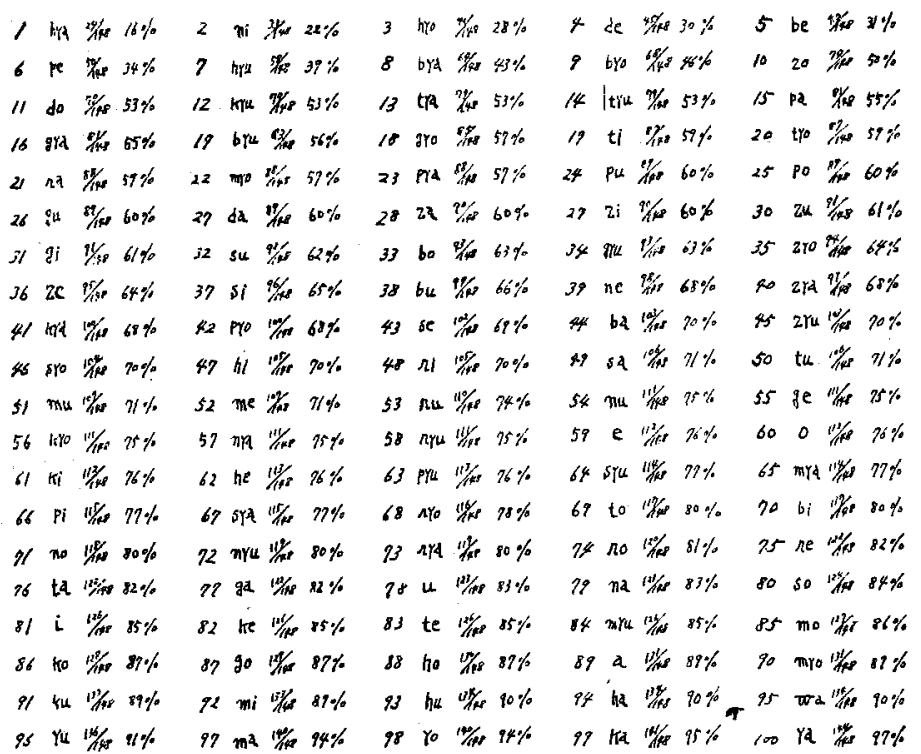

byo (92\%) hyu (93\%) hyo (93\%) …......pyo(100\%) であり,これら の平坞值は93\%であるから, ni よ り byo をでが正常耳でる比較的望 聴され易い語音である。

この平场明睹度以下には音は含 まれてなく，亩音群に属する語音は 11 ケ，拗音群に属する語㖰は11ケ， 共に同㧺であるのは與味がある.

ii）語音の强さ $45 \mathrm{sdb} K$ 対する正常耳の各単語 音の明睹佯

発信再生語音压が $45 \mathrm{sdb}$ レベル の則定に捈いては各語音について発 信 128 回行つた。

その明膫度は度6 表に示す如く明 瞭度の最小のものより順次に配列す オば ni (7\%) de (32\%) pe (43\%) $\mathrm{da}(45 \%)$ be $(53 \%)$ pa (56\%) hya $(60 \%)$ po $(60 \%)$ hyo (63\%) rya $(64 \%)$ do $(64 \%)$ gyo (66\%) ryo $(66 \%)$ ryu(67\%) nyu (69\%) nya $(70 \%)$ nyo (72\%) gyu (72\%) ri (73\%) ze (73\%) gya (73\%) hyu (74\%) sya(76\%) tya (77\%) kya $(80 \%) \cdot \cdots \cdot \cdot$ a $(99 \%) \cdots \cdot . \cdot$ yo $(100 \%)$ である.

これらの平朕明膫度は $40 \mathrm{sdb}$ は 70 sdb の場合の93\%に比して 79\% に低下゙ててる.

niより tya をでがこの場合の平

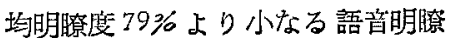
度を有している。

発信音の強さが $45 \mathrm{sdb}$ になつて も，母音はこの場合の明瞭度平埃值 より大なる明膫度を有している・こ の場合の平均明睲度以下の語音は直 谙群に属するすのは10ケ，拗音群に属するむのは14ケ である・

iii）語音の強さ30sdbに䴔する正常耳の各単

語音の明膫度

発信再生語音の強さが 30sdb レベルの時は，第 7 表 に示す如く各語音の発信回数は 160 回乞の正常耳に対す 
る綜合明瞭度は $63 \%$ である・

明膫度の最小なるものより順次に並べると po (13\%) ri (23\%) ……hyu (63\%)…..mi (100\%) である. po ょりne なでが平均明瞭度以下で有る.

母音の明睽度は他の語音に比して明瞭度がよく，平均 明際度以上であるが，発信音の強さが $30 \mathrm{~s} \mathrm{db}$ となると， 母音uのみが平均明膫度以下になる。

平竘明䁖度以下の 語音㥀音群化属するものは29 あり，拗音群に属するものは20 ケあつた。

語音の明膫度は発信の強さが $70_{s} \mathrm{db} 45 \mathrm{sdb} 30 \mathrm{~s} \mathrm{db}$ へ そ減少するにつれて明膫度の減少が起る・明瞭度の減少 の模様は，第 5 , 第 6 表の如く語音の順序に变化ないが $30 \mathrm{sdb}$ になると,この順序が第 7 表の如く幾分变化して くる.

\section{iv）感音系難聴耳の各単語音の明膫度}

第 8 袁は第 4 表の Matrix から計算される各語音の 病耳に対する明膫度で有る. 即ち明瞭度の最小（括坬内 は明瞭度を示す）のものから並べると，hya(16\%) ni $(33 \%)$ hyo $(28 \%)$ de(30\%) be(31\%) pe(34\%) hyu (39\%) by a (43\%) byo (46\%).... a (89\%) myo (89 \%) ku (89\%) ……yu (91\%) ma (94\%) yo (94\%) ka (95\%) уа (97\%) となつている.

病耳にあつても，母音は閒違いにくく，拗等群は比較 的間違い易い。

この平均明瞭度 69\% 以下にあるものは，直省群に属 する語音では de be pe zo do pa ti ra pu po gu da za zi zu gi su bo ze si bu ne の 22 ケであり，拗音 群に属する語音は hyo hyu 上下……pyo 迄の19 ケで 有る。

3) 行別讃徳模槉

100 語の再生語音の強さ $70 \mathrm{~s} d \mathrm{db} 45 \mathrm{sdb} 30 \mathrm{sdb}$ 及び病

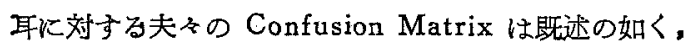
第1表，第 2 表，第 3 表，第4表であるが，これを更に 検詰するため行別の愦聴模榚を研究した。

i) 正常耳 $70 \mathrm{sdb}$ の行別俱聴模様

行別の誤聴模様は行別の小 Matrix の明瞭度の計算 によつて得られる・淕聴模様の最大なるるの，即ち明瞭 度の最小なるものから並べると d 行 $(61 \%)$ n 行 (84 \%) p 行 (91\%) b 行 (91\%) r 行 (93\%) g 行 (95 \%) $\mathrm{m}$ 行 $(97 \%) \mathrm{z}$ 行 $(97 \%) \mathrm{s}$ 行 $(98 \%) \mathrm{t}$ 行 (99 \%) h 行 $(99 \%) \mathrm{k}$ 行 $(99 \%) \mathrm{w}$ 行 (100\%) である. 抝音群の行別呮聴模様は, ny 行 (86\%) ry 行 (86\%) hy 行 $(88 \%)$ by 行 $(90 \%) \mathrm{gy}$ 行 (93\%) ky 行 (94
\%) sy 行 (95\%) zy 行 $(97 \%) \mathrm{my}$ 行 (98\%) py 行 (98\%) ty 行 $(98 \%)$ y 行 $(100 \%)$ である. 直音群で は d 行が說媤の程度が大である.しかしその他の各行 の言聴模様は，直音群，拗音群共に似ていて， $\mathrm{p}$ 行と py 行のみが明盼度飞差があり，前者 $91 \%$ ，後者 $98 \%$ であるが，他の語音についての誤聴模様は，明瞭度も順 序も殆んど同じである.

これらの行别誤聴は直晢群では直音群内に限られ，抝 音群では拗音群内に限られ，直音群に属する語音が泇音 群行誤聴されることは 70sdb では起らない，拗音群の 語音が直音群儿誤聴される現象, 即ら $\mathrm{y}$ の脱落である $\not 3$, kyu $\rightarrow$ tu kyu $\rightarrow$ te $\mathrm{kyu} \rightarrow \mathrm{ru}$ myo $\rightarrow$ mo ryo $\rightarrow$ yo

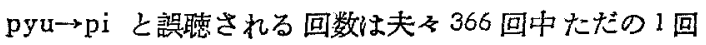
で稀である・

母音の誤聴も極めて稀で, $u \rightarrow m u 1 / 122, e \rightarrow b e 2 / 122$

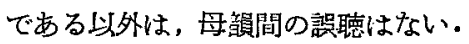

ii) 正常耳 $45 \mathrm{sdb}$ の行別語聴模榚

すでに迹べた $45 \mathrm{sdb}$ の第 2 表は 70sdb の第 1 表に 比して，その誤聴回数は増加するが，その模様は $703 \mathrm{db}$ の場合と大体同じである.

直音群では第 1 表比比して $\mathrm{d}$ 行 $\mathrm{p}$ 行 $\mathrm{n}$ 行の明瞭度 が減少している.その明暌度の最小なるるのから順に並 べること， d 行 (50\%) p 行 (69\%) n 行 (77\%) b 行 $(83 \%) \mathrm{z}$ 行 $(83 \%) \mathrm{r}$ 行 (88\%) g 行 (91\%) h 行 $(92 \%) \mathrm{t}$ 行 (95\%) m 行 (96\%) s 行 (97\%) k 行 (97\%) w 行 $(100 \%)$ である.

拗音群では明瞭度の最小なるものから配列すると, hy 行 (65\%) ry 行 (65\%) ny 行 $(70 \%)$ gy 行 $(70 \%)$ ky 行 (83\%) sy 行 (84\%) zy 行 (85\%) ty 行 (86 $\%$ ) by 行 (91\%) py 行 (93\%) my 行 (98\%) y 行 (99\%)であり，誤聴は直音群のむのに，誤聴される現 象は極めて少なく，bi $\rightarrow \mathrm{kyu}$ への誤聴 のみ 1/128 が認 められる上外に，直音群の誤聴はその糋内に限られてい る.

拗音群が直音群に 誤聴される回数は70s db より 45 sdb において僅かであるか堌加している. 即ら gyu $\rightarrow \mathbf{u}$ $(8 / 128)$ zyu $\rightarrow \mathrm{u}(6 / 128) \mathrm{kyu} \rightarrow \mathrm{ku}(2 / 128) \quad \mathrm{sya} \rightarrow \mathrm{sa}(2 /$ 128）以外性, syu↔si tyu $\rightarrow$ ti tyo $\rightarrow$ zo kya $\rightarrow$ na mya $\rightarrow \mathrm{u}$ myu $\rightarrow$ mi nyo $\rightarrow$ no nyo $\rightarrow$ mi nyo $\rightarrow$ mo $\mathrm{kya} \rightarrow \mathrm{ki}$ rya $\rightarrow$ ri ryu $\rightarrow$ u ryo $\rightarrow$ ro pyu $\rightarrow$ pi pyu $\rightarrow$ pi, は $1 / 128$ にすぎない，上上の如く拗音群の直音群への誤㯖は $\mathrm{y}$ の脱落が起る現象が主である・この外に y の脱落誤聴 と反対に ya が gyu に愦聴された現象が 1/128認めら 
れた。

母音の俱聴は70sdb では (3/122) で惯めてまれであ るが, 45sdb では，や〉增加してくる. 即ち第 2 表で は $\mathrm{u} \rightarrow \mathrm{mu}$ の誤㯖が $8 / 128$ e $\rightarrow$ he $か ゙ 3 / 128 \mathrm{i} \rightarrow$ bi $2 / 128$ でその他 $\mathrm{i} \rightarrow \mathrm{bi} d \rightarrow \mathrm{w}$.で $\mathrm{kiu} \rightarrow \mathrm{tu} \quad \mathrm{u} \rightarrow \mathrm{ni} \quad \mathrm{e} \rightarrow \mathrm{te} \quad \mathrm{o} \rightarrow$ bo は各々1/128である.

iii） 正常耳 $30 \mathrm{sdb}$ の行別無聴模様

再生語音の強さ $30 \mathrm{sdb}$ に対する正常耳の Confusion Matrix は既述の第 3 表であるが，愦聴が增加すると共 飞行別望聴の模様む異なつてくる.

直音群の行別望聴模様は明裺度の最小なるものから順 次化並べる， $z$ 行 (35\%) p 行 (38\%) d 行 (46\%) $\mathrm{s}$ 行 $(60 \%) \mathrm{k}$ 行 $(63 \%) \mathrm{b}$ 行 (64\%) g 行 (68\%) n 行 $(72 \%) \mathrm{r}$ 行 $(72 \%) \mathrm{h}$ 行 $(77 \%) \mathrm{t}$ 行 (82\%) $\mathrm{m}$ 行

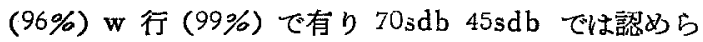
れなからた W 行 (wa のみ) の誤聴が7/160となつて いる:

拗皆群の愦㯖は hy 行 (41\%) ry 行 (43\%) ny 行 (45\%) gy 行 (46\%) zy 行 (47\%) ty 行 (56\%) by 行 (60\%) sy 行 (61\%) ky 行 (62\%) py 行 (78\%) my 行 $(93 \%)$ y 行 (93\%) で有る.

誤聴は主として各群内で起るが，直音群を拗音群仁誤 聴する率は $\mathrm{ra} \rightarrow$ pya $7 / 160 \mathrm{i} \rightarrow$ hyu $2 / 160 \mathrm{u} \rightarrow$ yu $2 / 160$ zo $\rightarrow$ ryo 2/160 ba $\rightarrow$ wa 2/160 であり, その他 ku-ryu $\mathrm{ke} \rightarrow$ pyu sa $\rightarrow$ sya $\mathrm{si} \rightarrow \mathrm{kyu}$ so $\rightarrow$ kyo so $\rightarrow$ hyo $\mathrm{nu} \rightarrow \mathrm{zyu}$ ro $\rightarrow$ yo pu $\rightarrow$ myu $z u \rightarrow$ ryo $z 0 \rightarrow$ gyo の誤㯖は $1 / 160 \mathrm{~K}$ 過ぎない。

拗音群では y が脱落して，直音群へ誤聴される現象 は少く, 即ち gyu $\rightarrow \mathrm{u} 24 / 160 \mathrm{zyu} \rightarrow \mathrm{u}$ 15/160 $\mathrm{ryu} \rightarrow \mathrm{u}$ $8 / 160$ byu $\rightarrow$ u $4 / 160$ ryo $\rightarrow$ u $3 / 160$ gyo $\rightarrow$ u $3 / 160$ kyu $\rightarrow$ ru $2 / 160$ nyu $\rightarrow$ u $2 / 160$ pyu $\rightarrow$ u $2 / 160$ で kyu $\rightarrow$ i sya $\rightarrow$ sa si $\rightarrow$ kyu so $\rightarrow$ kyo so $\rightarrow$ kyo nu $\rightarrow$ zyu ro $\rightarrow$ yo $\mathrm{pu} \rightarrow$ myu $z u \rightarrow$ ryo $z o \rightarrow$ gyo で其の他 $\mathrm{sya} \rightarrow$ ta tyu $\rightarrow \mathrm{i}$ ty $u \rightarrow$ u tyo $\rightarrow$ do myu $\rightarrow$ nu $\mathrm{kyu} \rightarrow \mathrm{u}$ myo $\rightarrow \mathrm{u}$ myo $\rightarrow \mathrm{mo}$ pyo $\rightarrow \mathrm{u}$ byo $\rightarrow \mathrm{re}$ が1/160 の割で有る.拗子韻は後に u が続くと $30 \mathrm{sdb}$ では y が脱落し嘼聴されるが，こ の現象は全体として少ない。

母音の諮聴は，その最大なるものより並べると u i o e a の順となり凚聴模樣は $\mathrm{o} \rightarrow \mathrm{u} 6 / 160 \mathrm{e} \rightarrow \mathrm{i} 3 / 160 \mathrm{u} \rightarrow$ i $2 / 160 \mathrm{i} \rightarrow \mathrm{e} 1 / 160$ で $70 \mathrm{sdb} 45 \mathrm{sdb}$ の強さに比して椌

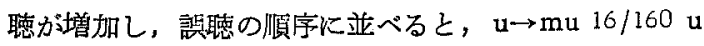
$\rightarrow$ hu $13 / 160 \mathrm{i} \rightarrow$ bi $10 / 160 \mathrm{i} \rightarrow$ ni $8 / 160 \mathrm{i} \rightarrow$ ri $8 / 160 \mathrm{u}$ $\rightarrow$ bu $7 / 160 \mathrm{i} \rightarrow$ mi $6 / 160 \mathrm{i} \rightarrow$ ki $5 / 160 \mathrm{i} \rightarrow$ pi $5 / 160 \mathrm{e} \rightarrow$ me $5 / 160 \mathrm{e} \rightarrow$ re $5 / 160 \mathrm{u} \rightarrow \mathrm{gu} 4 / 160 \mathrm{u} \rightarrow \mathrm{ku} 3 / 160 \mathrm{u} \rightarrow$ mu $2 / 160 \mathrm{u} \rightarrow \operatorname{mi} 2 / 160 \mathrm{u} \rightarrow \mathrm{pu} 2 / 160 \mathrm{u} \rightarrow \mathrm{yu} 2 / 160$ e $\rightarrow$ pe $2 / 160 \quad \mathrm{o} \rightarrow \mathrm{mi} 2 / 160 \quad \mathrm{o} \rightarrow$ go $2 / 160$ o $\rightarrow$ bo $2 / 160$ で有り, その他 $a \rightarrow$ ma i $\rightarrow$ zi u $\rightarrow$ ra $\quad$ e $\rightarrow$ ke $e \rightarrow t e ~ e \rightarrow$ de $\mathrm{e} \rightarrow \mathrm{be}$ o $\rightarrow$ ko o $\rightarrow \mathrm{mu}$ は各々 $1 / 160$ の吠聴である.

語音の強さが減岛马れて $303 \mathrm{db}$ の如くなると誤德の 外沁店のない場合も起つた. その回数の順序に並べる 之, u $10 / 160 \mathrm{mu} 7 / 160 \mathrm{su} 5 / 160$ zu $5 / 160 \mathrm{kyu} \mathrm{5/}$ 160 syo $5 / 160$ zyo $5 / 160 \cdot \mathrm{ki} 4 / 160$ tu $4 / 160$ hu $4 / 160$ go $4 / 160$ bo $4 / 160$ no $3 / 160 \mathrm{gu} 3 / 160 \mathrm{bu} 3 / 160 \mathrm{kyo}$ $3 / 160$ zya $3 / 160$ byu $3 / 160$ i $2 / 160$ e $2 / 160$ si $2 /$ 160 se $2 / 160$ ni $2 / 160$ hi $2 / 160$ mo $2 / 160$ gi $2 / 160$ ze $2 / 160$ zo $2 / 160$ zyu $2 / 160$ pyu $2 / 160$ gyo $2 / 160$ zyu2/160 ka ta ti te nu ra ri ro $\mathrm{za}$ da de do wa sya tyu nyu hya hyo myo ryo gya bya byo $\infty 1 /$ 160 で有る.

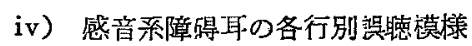

内耳性障碍耳の行別俱聴模樣は行別の Matrix の計 算によつて得られる。

直穴群では明膫度の最小なるるのより順次に亚べると $\mathrm{d}$ 行 $(47.9 \%) \mathrm{p}$ 行 $(57.2 \%) \mathrm{b}$ 行 (59.5\%) z 行 (60.2 \%) n 行 $(65.6 \%) \mathrm{s}$ 行 $(72.4 \%) \mathrm{g}$ 行 $(73.9 \%) \mathrm{r}$ 行 $(75.1 \%) \mathrm{t}$ 行 $(75.2 \%) \mathrm{h}$ 行 $(82.8 \%) \mathrm{k}$ 行 $(86.7 \%)$ $\mathrm{w}$ 行 $(91.2 \%)$ で有り，拗音群では my 行 $(28.8 \%) \mathrm{h}$ 行 $(27.7 \%)$ by 行 $(48.6 \%)$ ty 行 $(55.1 \%)$ gy 行 $(58.7 \%)$ py 行 $(63.5 \%) \mathrm{ky}$ 行 $(65.0 \%) \mathrm{zy}$ 行 $(70.0$ \%) sy 行 (75.2\%) ry 行 (78.1\%) y 行 (94.3\%) で 有る.

直音群では $d$ 行の明膫度が最も悪い，かつ h 行 $(82.8 \%) \mathrm{m}$ 行 (83.2\%) で明膫度は良好で有る. $\mathrm{t}$ 行 と ty 行, $\mathrm{g}$ 行之 $\mathrm{gy}$ 行の明瞭度は直音群と拗音群に は差が有るが，その他は似た傾向を持っている.

これらの行別俱聴は犆音群の諜聴は大体に括いてその 群内に限られ，拗音群も，その群内に限られているが， この傾向は既述の正常耳の場合と同栐である。

直音群に属するものでる抝音群に誤聴されるるのは， 次の如く極るて少ない。

pi $\rightarrow$ hyu $10 / 148 \quad \mathrm{re} \rightarrow$ ryu $9 / 148 \quad z a \rightarrow$ zya $4 / 148 \quad \mathrm{ni} \rightarrow$ nyu $3 / 148 \mathrm{pi} \rightarrow$ byu $3 / 148 \mathrm{za} \rightarrow \mathrm{rya} 3 / 148 \mathrm{zi} \rightarrow \mathrm{zyu} 3 / 148$ $z 0 \rightarrow$ yo $3 / 148 \quad z 0 \rightarrow 0 \quad 3 / 148 \mathrm{ki} \rightarrow \mathrm{kyu} \quad 2 / 148 \mathrm{sa} \rightarrow \mathrm{sya} 2 /$ $148 \mathrm{sa} \rightarrow \mathrm{hya} 2 / 148 \mathrm{ti} \rightarrow \mathrm{kyu} 2 / 148 \mathrm{ni} \rightarrow$ myu $2 / 148 \mathrm{mi}$ $\rightarrow$ yu $2 / 148$ gi $\rightarrow$ gyu $2 / 148 \quad$ ge $\rightarrow$ yo $2 / 148 \quad$ ze $\rightarrow$ yo 27 $148 \mathrm{ke} \rightarrow \mathrm{gyo} 2 / 148$; 以下のものは $1 / 148$ の稀な誤聴で 


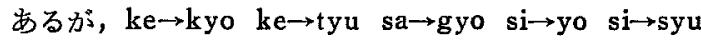
su $\rightarrow$ syu $\quad$ su $\rightarrow$ nyo se $\rightarrow$ sya $t i \rightarrow$ yu ti $\rightarrow$ hyo ti $\rightarrow$ zyu tu $\rightarrow$ ya tu $\rightarrow$ kya ni $\rightarrow$ yo ni $\rightarrow$ kyu nu $\leftarrow$ nyu no $\rightarrow$ yo me $\rightarrow$ gyu ra $\rightarrow$ ya ra $\rightarrow$ Iyu $\quad \mathrm{ri} \rightarrow$ hyu $\quad \mathrm{re} \rightarrow$ ya $\quad \mathrm{re} \rightarrow$ yu re $\rightarrow$ nyu re $\rightarrow$ gyo ro $\rightarrow$ zyo pi $\rightarrow$ nyu $p i \rightarrow$ pyu gi $\rightarrow$ tyu gi $\rightarrow$ hyu gi $\rightarrow$ zyu $\quad$ gu $\rightarrow$ ryu ge $\rightarrow$ ya $\quad$ ge $\rightarrow$ ryo $\quad$ za $\rightarrow$ ya $z i \rightarrow y u \quad z i \rightarrow k y u \quad z u \rightarrow y a \quad z u \rightarrow y o \quad z o \rightarrow$ pyu $\quad z e \rightarrow y u \quad z o$ $\rightarrow$ zyo ba $\rightarrow$ pya bi $\rightarrow$ byu wa $\rightarrow$ rya

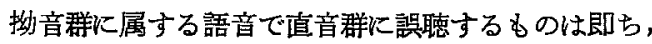
y の脱落するものは稀で有り，以下の通りである.

hya $\rightarrow$ sa $10 / 148$ syo $\rightarrow$ so $9 / 148$ zyu $\rightarrow$ zi $9 / 148$ tyu $\rightarrow$ ti $7 / 148$ ryu $\rightarrow$ ru $7 / 148$ kyu $\rightarrow$ te $6 / 148$ sya $\rightarrow$ sa $6 /$ 148 tyo $\rightarrow$ to $6 / 148$ syu $\rightarrow$ si $4 / 148$ sya $\rightarrow$ da $4 / 148$ syo $\rightarrow$ to $4 / 148$ gyu $\rightarrow$ gi $4 / 148$ kya $\rightarrow$ ra $3 / 148$ sya $\rightarrow$ ba $3 /$ 148 tya $\rightarrow$ ga $3 / 148$ tya $\rightarrow$ ba $3 / 148$ nya $\rightarrow$ wa $3 / 148$ hya $\rightarrow$ ra $3 / 148$ hyo $\rightarrow$ so $3 / 148$ myu $\rightarrow$ mi $3 / 148$ kyu $\rightarrow$ ti $3 / 148$ kya $\rightarrow$ ba $2 / 148$ kyu $\rightarrow$ gi $2 / 148$ kyo $\rightarrow$ to $2 /$ 148 syu $\rightarrow$ hi $2 / 148$ syu $\rightarrow$ gi $2 / 148$ syo $\rightarrow$ ro $2 / 148$ tyu $\rightarrow$ pi $2 / 148$ tyo $\rightarrow$ ra $2 / 148$ tyo $\rightarrow$ ro $2 / 148$ pya $\rightarrow$ wa $2 /$ 148 pyu $\rightarrow \mathrm{ki} 2 / 148$ zyu $\rightarrow \mathrm{gi} 2 / 148$ byu $\rightarrow$ pi $2 / 148$ kyu $\rightarrow \mathrm{ku} 2 / 148$ の以下は $1 / 148$ のもので

ya $\rightarrow$ ma ya $\rightarrow$ wa yo $\rightarrow$ re kyu $\rightarrow$ ki kyu $\rightarrow$ ku kyu $\rightarrow$ ke $\mathrm{kyu} \rightarrow \mathrm{ko} \mathrm{kyu} \rightarrow \mathrm{ge} \mathrm{kya} \rightarrow \mathrm{zi} \mathrm{kyu} \rightarrow \mathrm{bi}$ kyu $\rightarrow$ ta $\mathrm{kyo} \rightarrow$ pa kyo $\rightarrow$ bu sya $\rightarrow$ ga syu $\rightarrow$ he syu $\rightarrow$ pi syu $\rightarrow$ pi syu $\rightarrow$ ge syo $\rightarrow$ su syo $\rightarrow$ ra syo $\rightarrow$ ba tye $\rightarrow$ ra nya $\rightarrow$ ma nyo $\rightarrow$ na hya $\rightarrow$ hu hyu $\rightarrow$ hi hyu $\rightarrow$ pi hyo $\rightarrow$ ko hyo $\rightarrow$ te hyo $\rightarrow$ ba myo $\rightarrow$ mo myo $\rightarrow$ me ryu $\rightarrow$ i ryu $\rightarrow$ hu ryu $\rightarrow$ mi ryu $\rightarrow$ bu pya $\rightarrow$ ra pya $\rightarrow$ pe pyu $\rightarrow$ hu gyu $\rightarrow$ ki gyu $\rightarrow$ zi $z y u \rightarrow$ si bya $\rightarrow$ ha bya $\rightarrow$ ra byu $\rightarrow$ ra byu $\rightarrow$ ri である.

母音の詰聴は正常耳では極めて稀であるが，感音系障 碍でも稀で有る・即ち

o $\rightarrow$ ho $14 / 148 \quad$ a $\rightarrow$ ba $12 / 148 \quad e \rightarrow$ i $12 / 148 \quad u \rightarrow$ mu 10 $/ 148$ o $\rightarrow$ po $7 / 148$ o $\rightarrow$ bo $7 / 148 \mathrm{i} \rightarrow$ ri $6 / 148$ e $\rightarrow$ te $5 /$ $148 \mathrm{e} \rightarrow$ be $5 / 148 \quad$ a $\rightarrow$ ha $4 / 148 \quad \mathrm{i} \rightarrow \mathrm{mi} \quad 3 / 148 \quad \mathrm{i} \rightarrow \mathrm{bi} 3 /$ $148 \mathrm{u} \rightarrow \mathrm{bu} 3 / 148 \mathrm{e} \rightarrow \mathrm{re} 3 / 148 \mathrm{i} \rightarrow \mathrm{ni} \quad 2 / 148, \mathrm{u} \rightarrow \mathrm{mi} 2 /$ $148 \mathrm{u} \rightarrow \mathrm{mo} 2 / 148 \mathrm{u} \rightarrow \mathrm{da} 2 / 148 \mathrm{e} \rightarrow \mathrm{ge} 2 / 148 \mathrm{e} \rightarrow \mathrm{de} 2 /$ $148 \quad \mathrm{o} \rightarrow \mathrm{ro} \quad 2 / 148 \quad \mathrm{u} \rightarrow \mathrm{i} \quad 2 / 148 \quad \mathrm{o} \rightarrow \mathrm{e} \quad 2 / 148 \mathrm{i} \rightarrow \mathrm{u} \quad 2 / 148$ で, その他 $\mathrm{a} \rightarrow$ pa i $\rightarrow$ ki i $\rightarrow$ hu i $\rightarrow$ mu i $\rightarrow$ pi i $\rightarrow$ gi i $\rightarrow$ zi $u \rightarrow$ nu $u \rightarrow$ ho $u \rightarrow$ ru $\quad \mathrm{e} \rightarrow \mathrm{o} \quad \mathrm{e} \rightarrow$ ro $o \rightarrow$ to $\mathrm{o} \rightarrow$ no $o \rightarrow$ bu $0 \rightarrow$ yo の $1 / 148$ である.

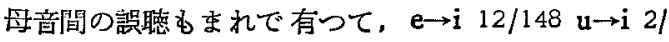

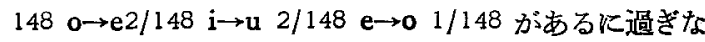
W.

4）群別に括ける子韻の愦聴模様

正常耳及び病耳でも子韻の䛃聴は第 1，2，3，4 表の如く

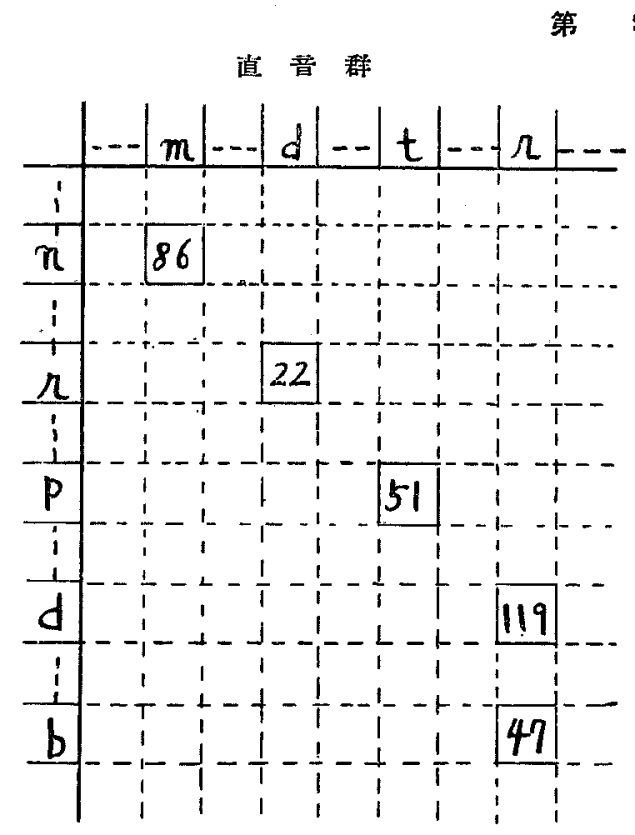

表

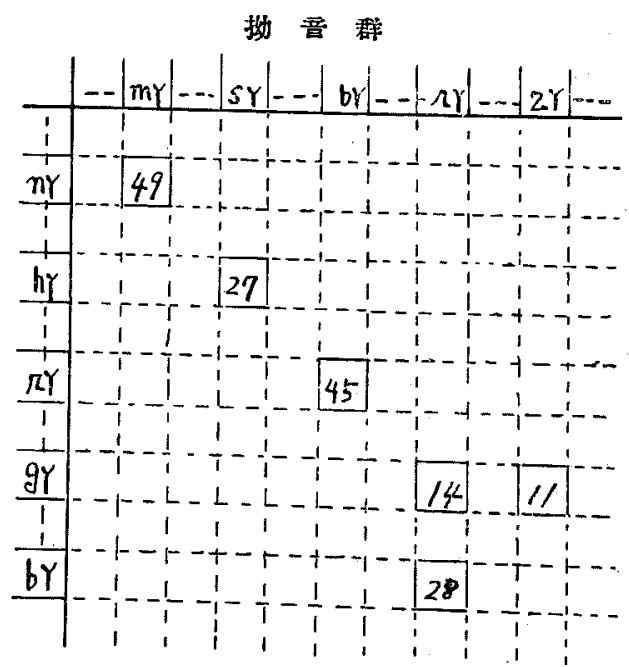


面 害 稳

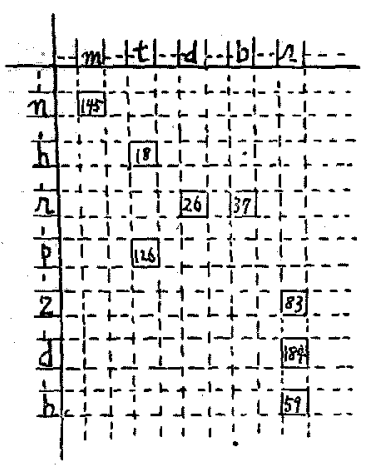

第 10 春

物 晋 群

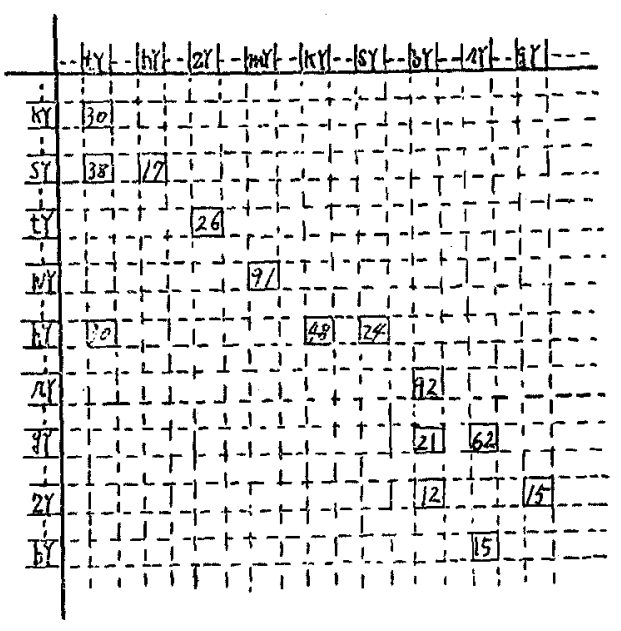

\section{第 11 表}

直霄群

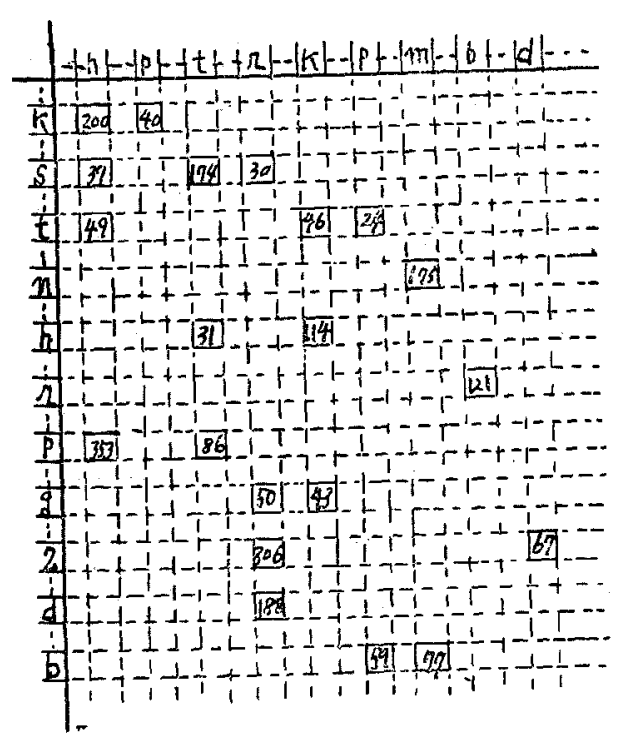

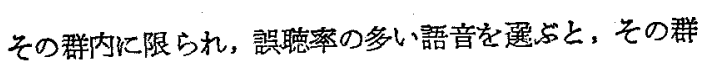
内の子㗊間に一定の傾向が認められる・

i) 再生語音 $70 \mathrm{sdb}$ 亿対与る 正常耳の 新別子間に

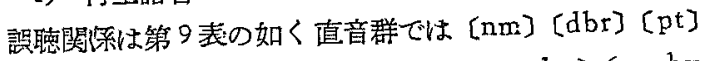
であり，拗音群炕括いては〔ny my] [ry by] [gy by ry)である.

ii）再生語音 $45 \mathrm{sdb}$ 亿対する正常耳の直音群内子韻

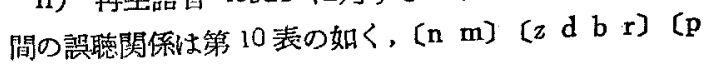

\section{肳 亯}

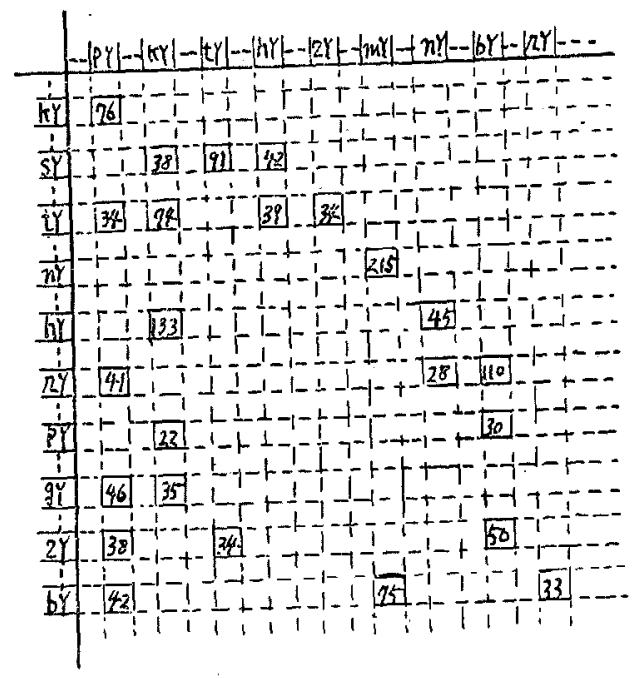

$\mathrm{h}$ t了となり 70sdb のそれより z, h の子韻が加かり，

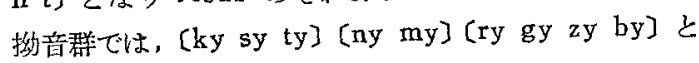
なり zy 文び〔ky sy ty〕が加わる。

iii）再生語音 $30 \mathrm{sdb}$ 亿対する正常耳の群内子獣間 の䛊聴関係は第 11 表の如く，直音群では $70 \mathrm{sdb} 45 \mathrm{sdb}$ と比して, その就聴模㥞が複雜になつて, 新らしく b k s g の子䫓の誤聴が増加する。

拗音群に和いても by ky py ry の拗子䫏か゚加わる。 


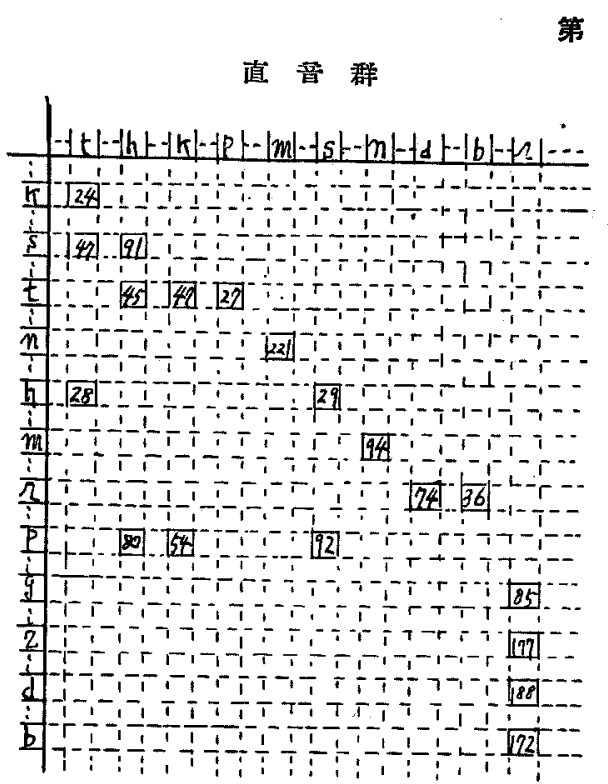

iv）感音系障碍耳の諆聴模樣は第 12 表の如く直音群 においては [n m] のみは正常耳. (70;db) 々辰様であ るが諟聴模様が拡大し [s t p h] [ k] となり拝音群では (gy zy by ry) [hy sy) [ty py ky] [ky hy ty] となつていろ.

5）正常耳及び病耳にも誤聴され易い語音

既述の如く 2）3）により日本語音の全部である 100 語に扮いて，正常耳及び病耳において子語音誤聴はその 群内に扎いてのみあり，他群への誤聴は殆儿どない。

第 5，6，7，8 表上り直音群偶する語音で 正常耳及び 病耳に対し，共通して俱聴され易い語音をみると ni de be pe da do であり，拗音群に属する語音で共通して 誤聴され易い語音は hya bya のみであり，直音群に比 して少ない。

\section{第 5 章＼cjkstart新語音表とその成績}

語音聴力検查は語音表に対する被検者の空答の成績に もとずいているから測定者間に招いて語畗表は，共通の ものを使用しなければならないが，口ガトム，会語率， 平等率，数表，等が有り，湘定者各自の根㚭にもとずい て夫々異なつた語音表で測定を行っているからこれら の成續は共通したものとはなり難い。

その上語音表に選ばれた語音群は誤聴荧㥞のデーター より作幣されるべきで有るが，これがまだ行われていな い.故に著者は誤聴模様により得られたデーターより合 理的な語音表を作製せんと企てた.その根拠は次の如く
12 表

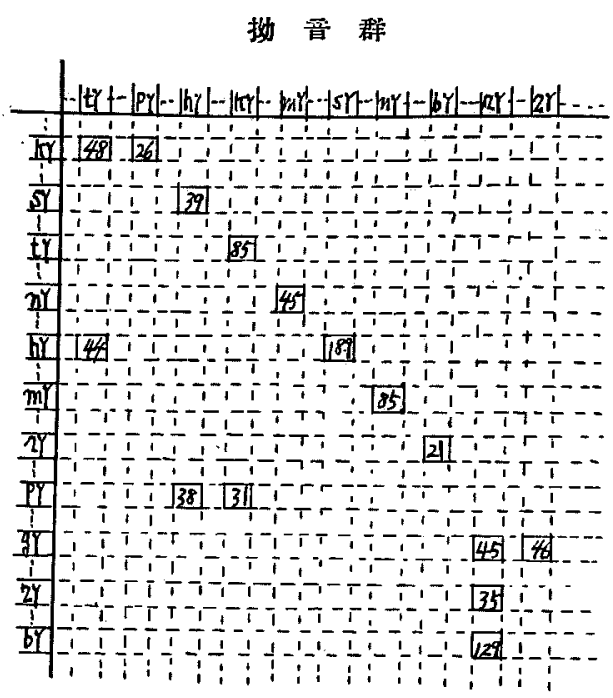

で有る。

1）日本語 100 語の詋聴模様は正常耳に执いても，感 音系障碍耳に和いても，直音群，拗音群を通じて一定の 傾向が認められる。

2）正常耳及び病耳に共通して著しく誤聴し易い語音 は語音表より除外すべきで有り，その反対に感音系障碍 耳に対してる著しく良好な明瞭度を有する語音は病耳間 の語音聴力の相違の判定が明瞭でなくなるからこのよう な語音は除外すべきで有る・

3）これに反して語音入力が減少するにつれて誤聴率 が平行して㙕すような語音を語音表に取り入れねばなら ない.

4）諮聴の群内模様よりして直音群と拗音群は既述の 如く同一傾向の模様であるから，直音群の語音のみを採 用しても良い。

以上の理由よりしてデーダーを整理すると直音群は 67 語ありその内, 正常耳でも誤聴し易い語音は，即ち 語音表炕採用してはならない語音は ni de be pe da do である・

感音系障碍耳に対して明瞭度の最小なるものより順に 60 語を採用した。

この語音群を前半と後半に 30 語つつに分けて, 前半 を $\mathrm{A}$ 表、挠半を $\mathrm{B}$ 表とした。

A 表は難聴語音表，B 表惊聴語音表であり，第 13 表の如くである. 


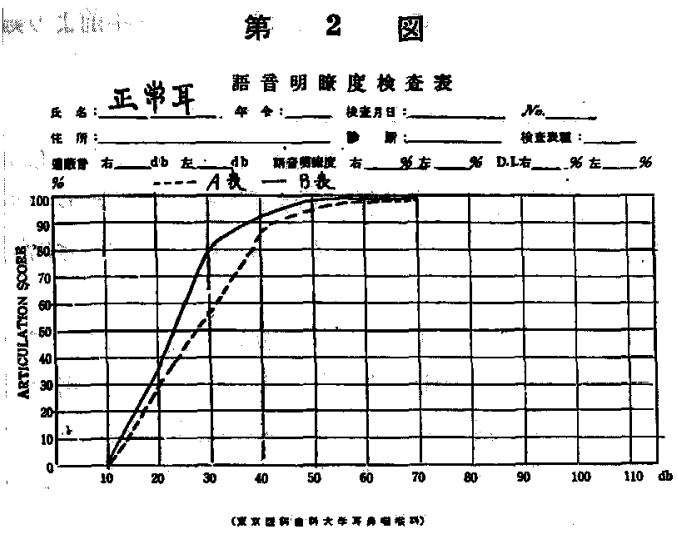

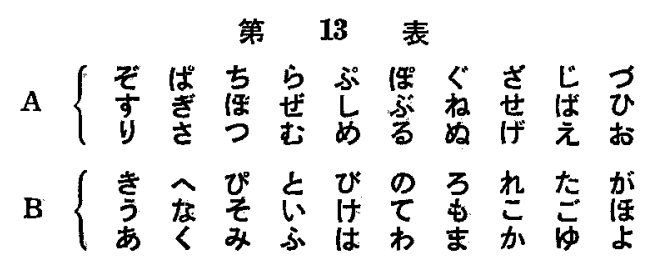

先つ A 表の各語音を 3 秒間隔，マイクロホン前面音 压 70phone の強さで NHK 女子アザンサーによつて 30 語録音し，次いで 30 秒間隔を和いて B 表を録音し た。

被検者は正常耳の sensation Level から 10db ステ ップで最大明瞭度が得られる迄測定を行つた。

第 3 図
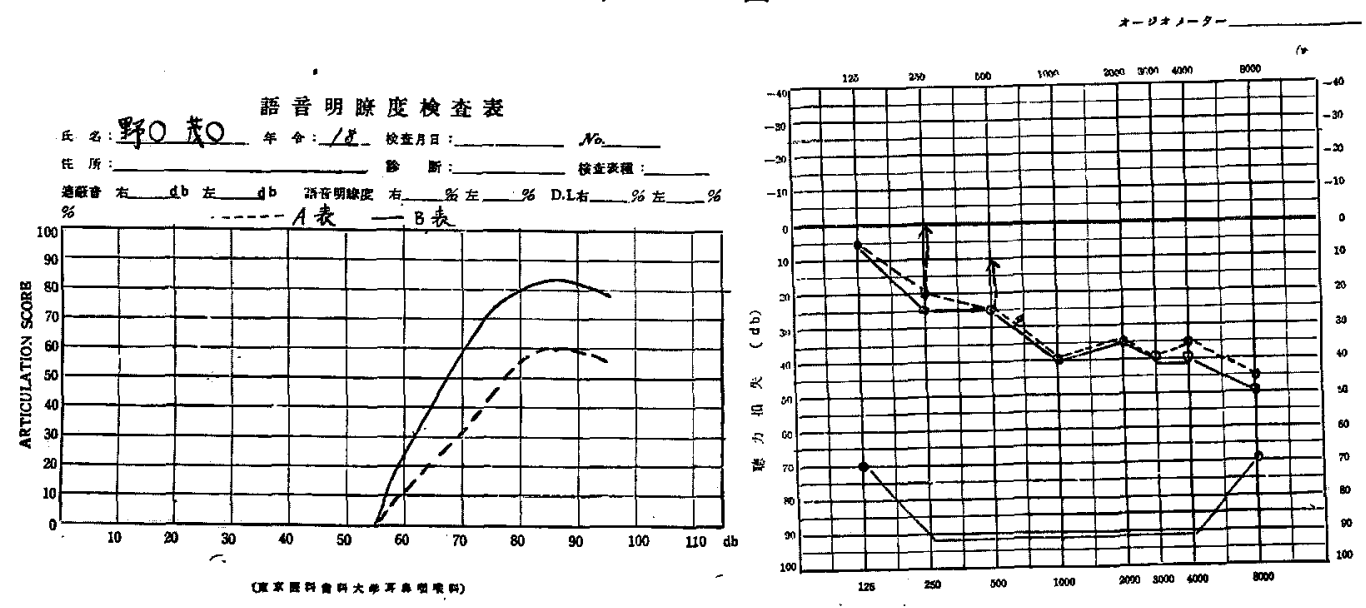

O 右

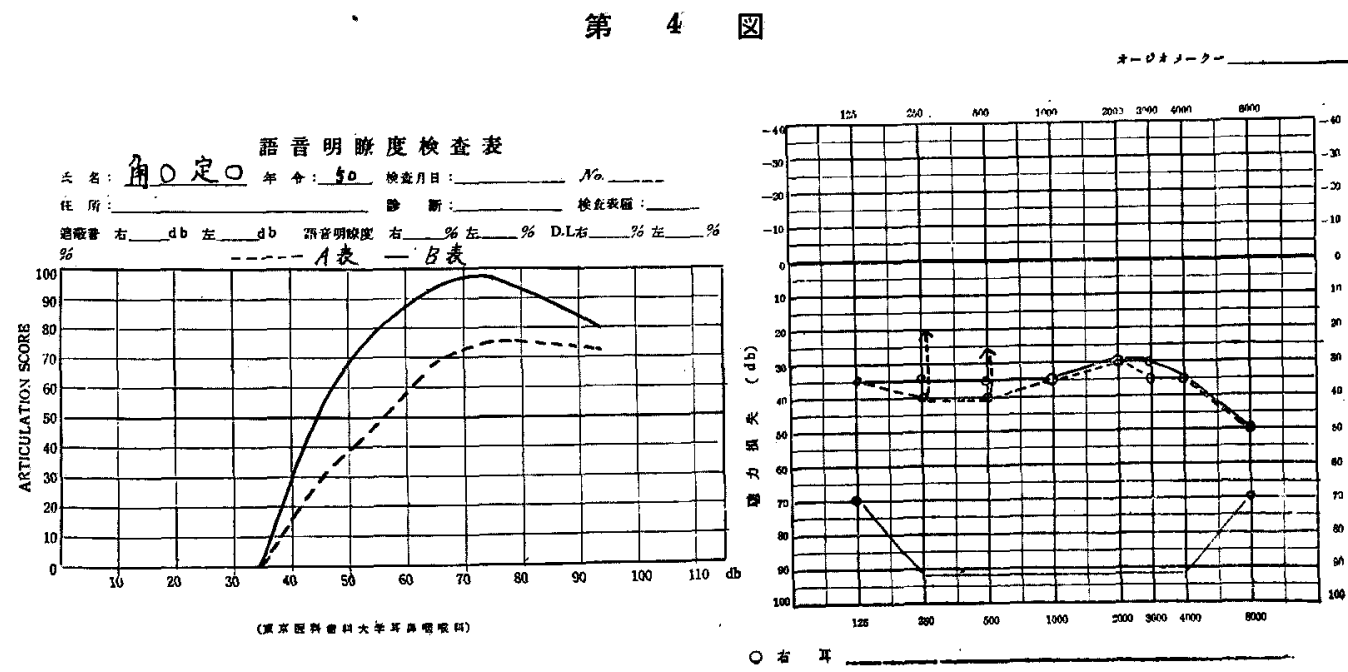


2) 成 績

i） A 表，B 表に対する正常耳の 成績は 第 2 図江示す如く

A 及び B 明膫度曲線は語音の強さ $0 s \mathrm{db}$ 及び $70 j \mathrm{db}$ 附近では一致するが，その中間の強さでは A B 曲線は 離れて，30sdb に特いては最大の相違を示し 20〜30\% の間隔が有る・A 支び B 表に対して，正常耳の明膫度 曲線が特有な形状を呈する事実が認められたが，これが 病耳に対してどのようになるかを調べた。

ii） A 及び B 表に対する感音柔障碍耳の 明瞭度成績

（A） 野 $\bigcirc$ 茂 $\bigcirc .18$ 才. 男. 両側内耳性難聴，鼓膜正
常，通気度良好，その他に異常なし・約 10 年前より菶 聴となつた。

中等度の内耳性難聴で第 3 図に示寸如く .

語音明瞭度曲線は 85sdb で頭打ちの型であり，しか ๖， A 表曲線と B 表曲線は最大明膫度 $85 \mathrm{sdb} \nu$ ベ でる，正常耳と異なつて離間のあるのは注目すべき所見 で有る。

(B) 角O定O. 50 才. 男. 両側内耳性難聴オージオ グラムは，水平型の中等度の難聴耳であり，鼓膜稍々溷 濁して和るが，通気度良好，約 8 年前より萪聴，耳鳴を 自覚す被検者の最大明膫度 $75 \mathrm{sdb}$ レベルに括いて A 及び B 表の 明膫度の間には $20 \%$ の離間がある第 4 图

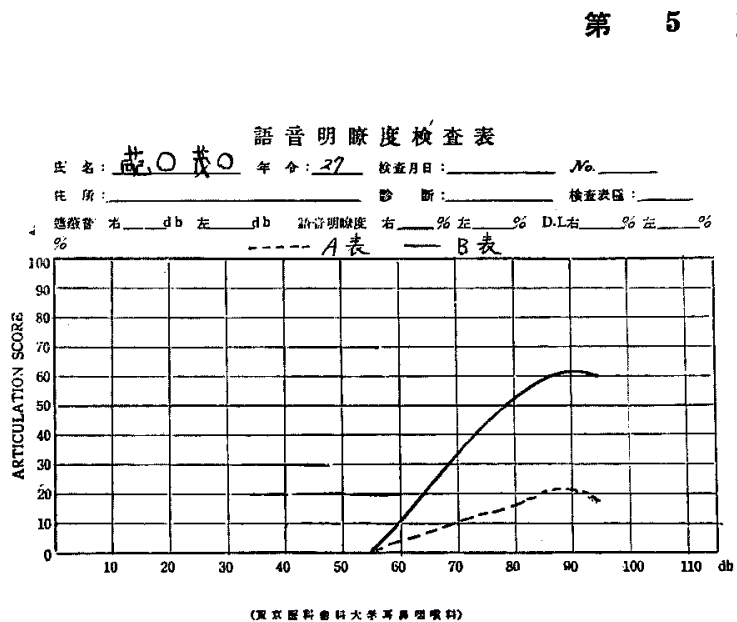

図

第 6 図
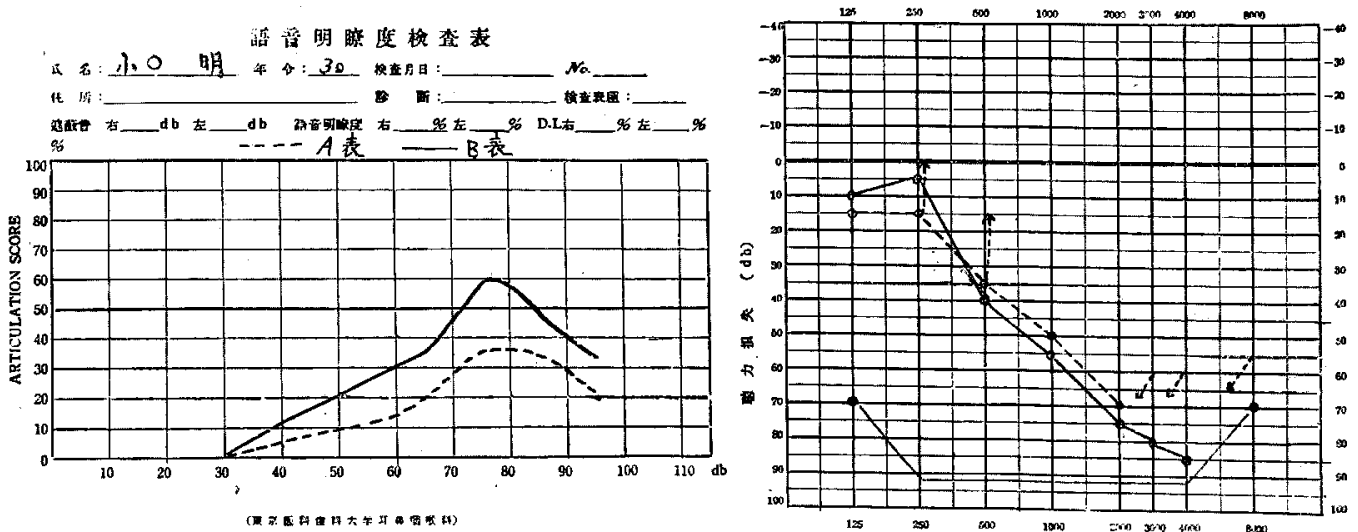

$0 \div$ II 

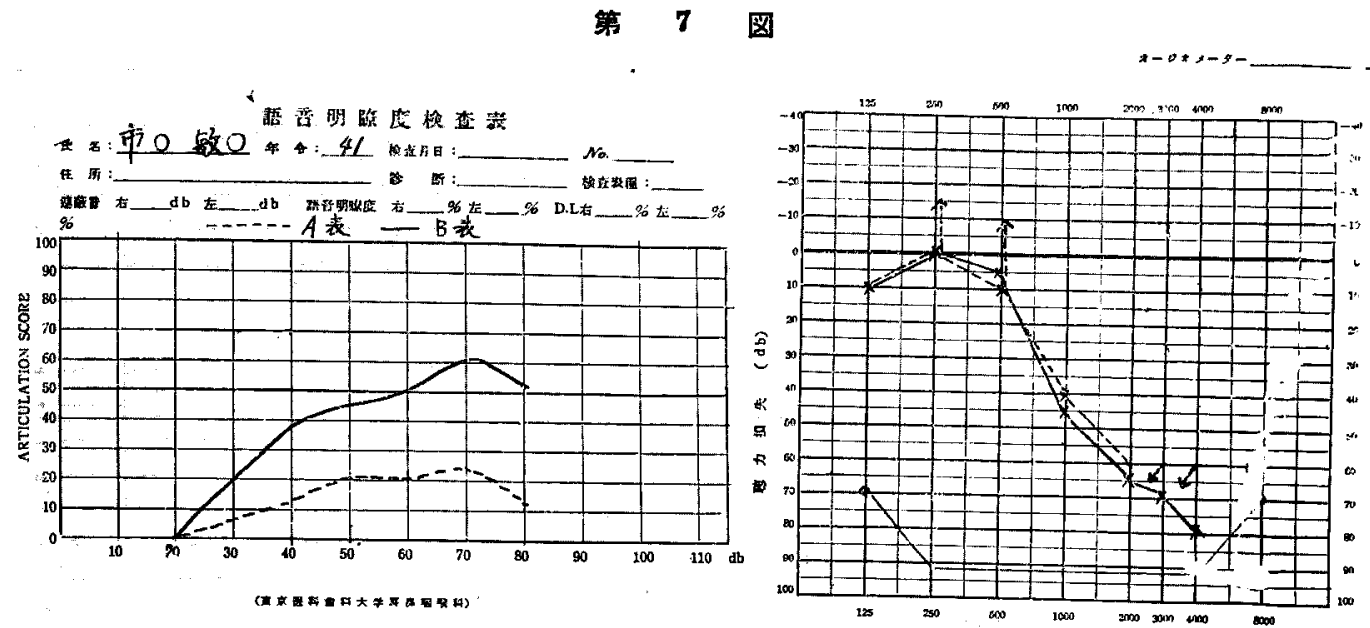

아 1 II

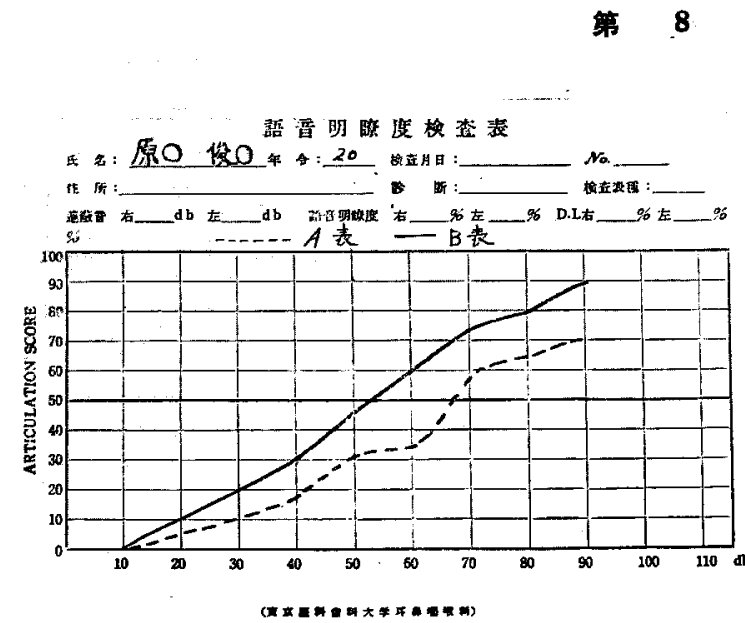

図

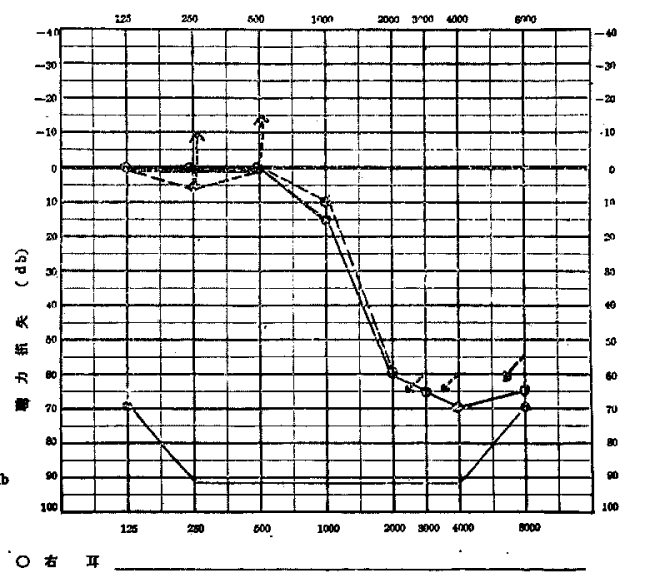

参照.

(C) 蓜○茂O.27 お.女. 現在鼓膜正常であるが高 度内耳性難聴で耳鳴を訴へている.被喻者の最大明睹度 $85 \mathrm{sdb}$ に执いて A 表明膫度と B 表明瞭度の嚾間は 40 \%である第 5 図参照.

(D) 小O明○. 30 才. 男. 内耳性難聽，そのオージ

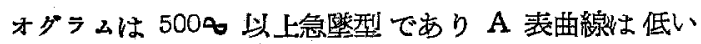
明膫隻を保持し，被榆者の最大明睦度 $75 \mathrm{sdb}$ レベルに 执いて，A 及び B 明瞭度曲線に $25 \%$ の㒕間がある第 6 図参照.

(E) 市○敏○・41 才. 男. そのォージオグラムは

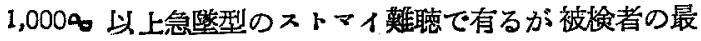

大明瞭度 $70 \mathrm{sdb}$ に和いて，その A, B の明睹度曲線間 に $37 \%$ の離間がある第7 図参揑・

（F） 原O俊○. 20 才。男. オージォグラムは 2,000 $\infty$ 急隥型内耳性難聴，約 6 年前上り耳鳴を訴人，その 後次第に難聴となる・その最大明暸度の $90 \mathrm{sdb}$ レべル において 両表の 明瞭度曲線間に $20 \%$ の離間がある 第 8 図参照.

(G) 中O友O. 45 才. 男. $x=x ー ル$ 氏症候群の患 者で $3,000 \bowtie$ 急酶型のオージオグラムであり，その明 膫度む以上の例上りは相当良好であるが，被検者の最大 明膫度の 60sdb レべルに括いて，A 及び B の明瞭度 曲線間は $20 \%$ の離間がある第 9 図济照。 

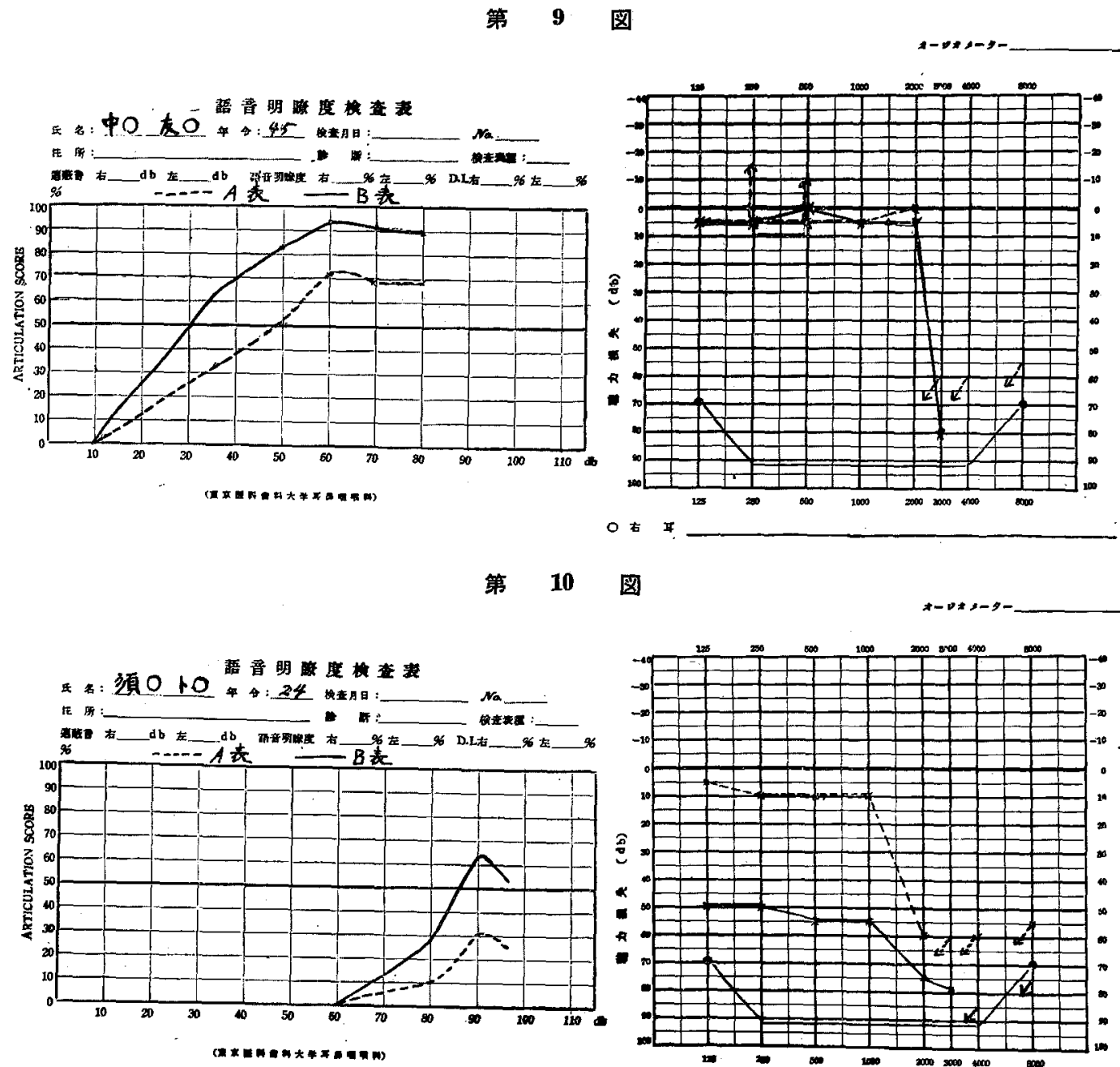

国

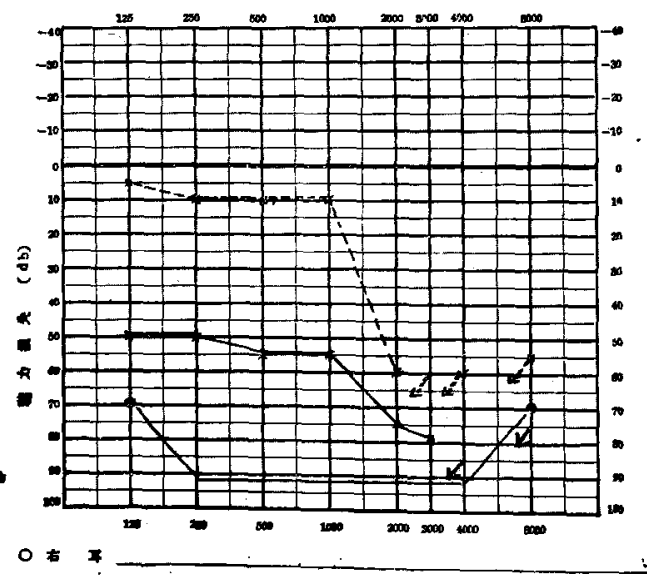

（H）須O 10.24 才. 女. 左混合性難聴，10才の 時に肺炎に䍜患し，その後次第に難聴になり，21 䪱 にも耳漏が有つた、両鼓膜に中等度の第孔あり，通気良 好・オージオグラムは混合型.

被検者は90sdb で最大明膫度が得られ，このレベル

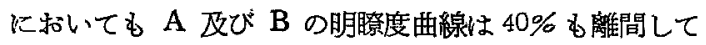
いる第 10 図丢照.

第3図から第 10 図汽認められる如く感音系障碍耳で は最大明瞭度に括いても A 及び B の明睧度曲線間が 著しく離れて $20 \%$ 以上になつている、この病耳の曲線 所見は，正常耳の最大明䐀度では A B 曲線が一致して いる所見に比して著しい相違である．Ａ及び B 表炕よ
る, 湘定値の相違よりして感音系障碍耳と正常耳の鑑星 䛦断が正確に行える.

\section{第 6 章 要 約}

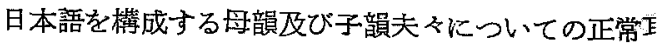
の語音明膫度 Matrix で整理し 語音間の淤聴模様を有 究した.

正常耳取び病耳について誤聴模樣が Matrix によ一

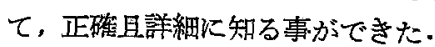

正常耿物いて語音の強さが減少はるにつれて増大 る誤聴模様は聴力の低下している感音系障碍耳の誤㯖 様と，ほとんど良く似ている・故に合理的な語音検查訲 が作彆される可能性を発見した。 
誤聴模様よりして，正常耳においても誤聴し易い誤音 は除去し，直音群と拗音群の誤聴模様は類似しているの で，直音群のみの語音を策め，之等を明瞭度の最も悪い すのより，順次に良好なるもの充と取り，60語を採用 し，新らしい，語音表を得た・これに反して，従来多く 使用されていた語音表（会話率、平等率）では，その頻 出率の関係より，同一語音が 2,3 ケ出現する。

例へば ka ma sa si ro o ta $i$ tu no yo da であ るが，この語音個くを Matrix 方式で得た著者の語音 嘲膯度より検すると，正常耳については， ka 100\%， ma $100 \%$ sa $99 \%$ si $97 \%$ ro $97 \%$ o $100 \%$ ta $100 \%$ i $100 \%$ tu $99 \%$ no $80 \%$ yo $100 \%$ da $73 \%$ で特に no 上 da が平均明瞭度より著しく低いに拘らず，他の 語音は皆 $100 \%$ 明瞭度に近いのは語音表として語音の組 合せが不明瞭のように思われる，乙かし会話は明瞭度の 良い語音が自然に組合せられているのは興味ある事実で 有る.

亦感音柔障碍耳のブーター上りすれば明瞭度の平均値 が69\% の場合比 69\% 以下の 明膫度のものは sa si tu $\mathrm{da}$ のつであり，他の語音は皆平均明瞭度より上位に あるのである・かかる語音が会話率語音莍では 2 回以上 同一語音表に出現することは語音表として語音聴力につ いての病耳間の，小なる差異が測定でないであるう。

新語音表より，A，B 明膫度曲線を 比较する事に上 $\eta$ ，感音䒺障碍の鑑別が容易になり今後この方面の忘用 が期待される.その外火各語音について楊られた明瞭度 及び誤聴模様は通信関俰において，ロガトムに代る語音 表を作製し得る根抛を与光るであらら。

\section{文献}

1) Fleicher, H.: Speech and Heating D.

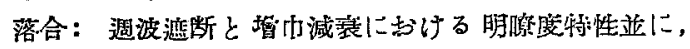

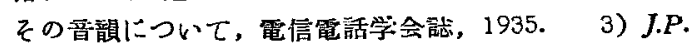
Egan: Articulation Testiug Methods, Laryngoscope Vol.58, No.9, 955, 1948.4 4) 令䖯克已:

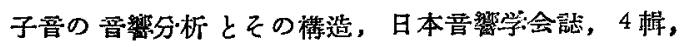
1943 (沼 19). 5) Davis, H.: The articulation area and the social adeguacy index for hearing, Laryngo-scope, $58,761,1948 . \quad$ 6) Bease!y, W.C., Rassenwasser, H.: Determing factor in composing and analyzing speech-hearing test (Part I)

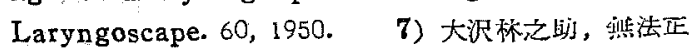
夫：日本語語音に依る聴力梌盉の甚礎，1，23（妿26）

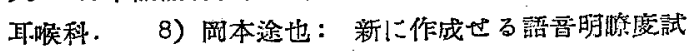

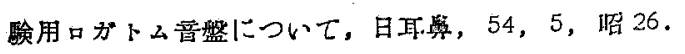

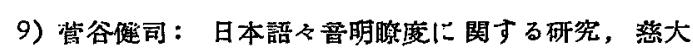

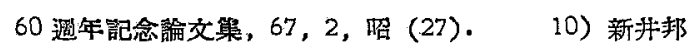
夫: Speech Audiometry 日耳鼻，56，11 (炤 28).

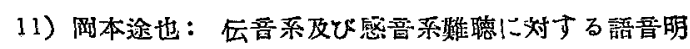

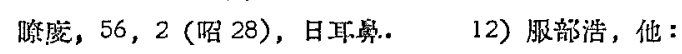

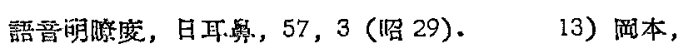

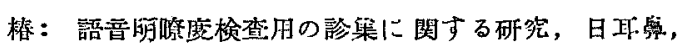
57,10 (炤 29). 14) 弪田, 武山：日本語音明暸

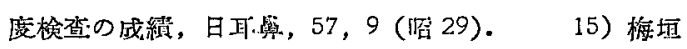

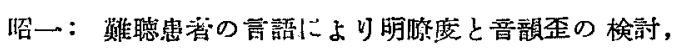

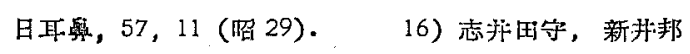
头：臨有応用を旨とした譛音オージオメトリーに゙就い て, 26,5, 䎏 29.17 ) 吉田, 武山：語音聴力検

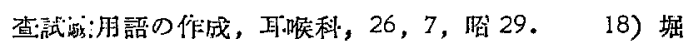

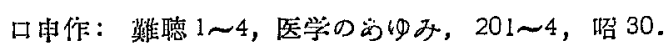
19) 武山貢次：純曋聴门と語音聴力との関係, 日耳

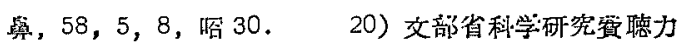

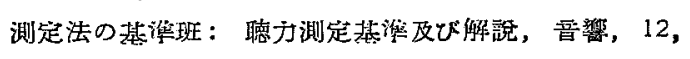
2, 沿 30. 21) J.A. Miller, P.E. Nicely: An Analysis of perceptional Confusions Among some Englisch Consonants, 338, 2, $1955 . \quad 22)$ 新并邦

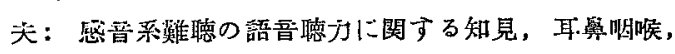

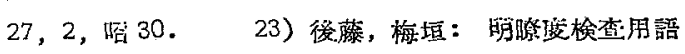

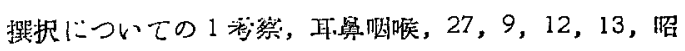
30. 24) 吉田前八: 日本語百の諤聴現像に関与る

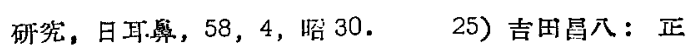

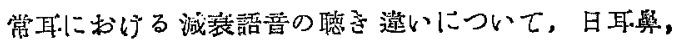
58, 11, 炤 30. 26) Clair N. Hanley: Factorial Analysis of Speech Perception. J. Speech and Hearing Disorde 76, 5, 1956.27$)$ 伊藤毅：日 本語娄の Confusion Matrix に゙ついて，日本音隌学

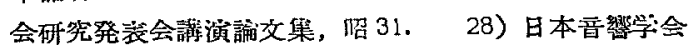

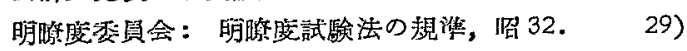

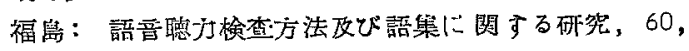
8, 嘫 32. 30) 八憣重一：吾，岩波全書. 31) 服部四郎：音響学, 岩波全書·

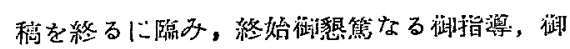

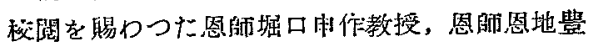

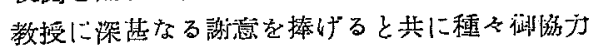

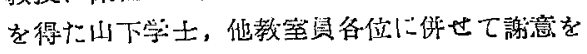
登す。なほこの小諞交を亡父に捀ぐ・

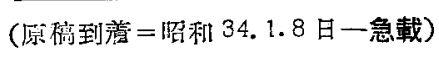

